\title{
1 Characterization of uranium redox state in organic-rich Eocene sediments
}

3 Susan A Cumberland ${ }^{1,2,3}$, Barbara Etschmann², Joël Brugger ${ }^{2}$, Grant Douglas ${ }^{4}$, Katy Evans ${ }^{5}$,

$4 \quad$ Louise Fisher ${ }^{6}$, Peter Kappen ${ }^{3}$, John W. Moreau ${ }^{1}$

51 School of Earth Sciences, University of Melbourne, Parkville, Victoria 3100, Australia

62 School of Earth, Atmosphere and Environment, Monash University, Clayton 3800, Victoria,

7 Australia

83 ANSTO Australian Synchrotron, 800 Blackburn Road, Clayton 3168, Victoria, Australia

94 CSIRO Land and Water, Floreat, Western Australia, Australia

105 Western Australian School of Mines, Curtin University, Bentley, Western Australia, 11 Australia

126 CSIRO Mineral Resources, Bentley, Western Australia, Australia

14 Abstract

The presence of organic matter (OM) has a profound impact on uranium (U) redox cycling, either limiting or promoting the mobility of $U$ via binding, reduction, or complexation. To understand the interactions between $\mathrm{OM}$ and $\mathrm{U}$, we characterised $\mathrm{U}$ oxidation state and speciation in nine OM-rich sediment cores (18 samples), plus a lignite sample from the Mulga Rock polymetallic deposit in Western Australia. Uranium was unevenly dispersed within the analysed samples with $84 \%$ of the total $U$ occurring in samples containing

$21>21$ wt. \% OM. Analyses of $U$ speciation, including $x$-ray absorption spectroscopy and bicarbonate extractions, revealed that $\mathrm{U}$ existed predominately $(\sim 71 \%)$ as $\mathrm{U}(\mathrm{VI})$, despite the low pH (4.5) and nominally reducing conditions within the sediments. Furthermore, low 
extractability by water, but high extractability by a bi-carbonate solution, indicated a strong association of $\mathrm{U}$ with particulate $\mathrm{OM}$. The unexpectedly high proportion of $\mathrm{U}(\mathrm{VI})$ relative to $\mathrm{U}(\mathrm{IV})$ within the OM-rich sediments implies that $\mathrm{OM}$ itself does not readily reduce $U$, and the reduction of $U$ is not a requirement for immobilising uranium in OM-rich deposits. The fact that $\mathrm{OM}$ can play a significant role in limiting the mobility and reduction of $\mathrm{U}(\mathrm{VI})$ in sediments is important for both U-mining and remediation.

Keywords: Mulga Rock, uranium, mobility, organic matter, oxidation state, x-ray absorption spectroscopy.

\section{Highlights}

- $84 \%$ of $U$ in Mulga Rock OM-bearing sediments occurred within the OM-richest samples (>21\% total organic carbon; 9 of 18 samples).

- $71 \%$ of $U$ was present in the $\mathrm{U}(\mathrm{VI})$ oxidation state.

- Higher proportions of $U$ occur as $\mathrm{U}(\mathrm{VI})$ in mature OM-rich sediments than previously thought.

- $\mathrm{OM}$ strongly complexes $\mathrm{U}(\mathrm{VI})$, limiting its mobility and reactivity.

- $\mathrm{U}$ reduction processes are not ubiquitous within OM-rich sediments.

\section{Introduction}

41 The mobility of uranium (U) in natural environments is controlled by its oxidation state and solubility, with the uranyl ion $\left(\mathrm{U}^{\mathrm{V}} \mathrm{O}_{2}{ }^{2+}\right)$ generally more soluble than $\mathrm{U}(\mathrm{IV})$. Ligands such as $\mathrm{CO}_{3}{ }^{2-}, \mathrm{OH}^{-}, \mathrm{PO}_{4}{ }^{3-}$ and $\mathrm{SO}_{4}{ }^{2-}$ can either increase (via formation of stable aqueous complexes) or decrease (via formation of insoluble minerals) U mobility (Cumberland et al., 2016).

45 Uranium mobility is also influenced by organic matter (OM) in both dissolved and colloidal/particulate forms (Wood, 1996; Cumberland et al., 2016). Depending on pH, 
47 dissolved OM such as humic and fulvic acids can bind $U$, facilitate its transportation, and

48 prevent its sorption to mineral surfaces (Luo and Gu, 2008; Zhao et al., 2012; Tinnacher et al., 2013). In contrast, particulate or solid phase OM can adsorb and accumulate U, resulting in the formation of OM-rich sedimentary $U$ deposits (Greenwood et al., 2013; Cumberland et al., 2016). While considerable information exists on $U$ mobility in inorganic systems (Grenthe et al., 2004), datasets for organic-rich systems are comparatively deficient (Bargar et al., 2013). The complex molecular-scale associations of $U$ and $O M$, and the impact of OM on $U$ mobility/immobilisation, are still being unravelled (Bargar et al., 2013). These knowledge gaps limit development of in situ mining technologies (Zammit et al., 2014), as well as environmental management and remediation strategies for $\mathrm{U}$ mining sites.

Recent studies have been directed towards understanding $U$ mobility in OM-rich modern sediments, including the pathways through which $U$ potentially accumulates (Tokunaga et al., 2005; Law et al., 2011). Peat, for example, can concentrate $U$ by up to factor of 10,000 from groundwater containing ppb level U concentrations (e.g. (Idiz et al., 1986; Read et al., 1993; Owen and Otton, 1995; Lidman et al., 2012)). Bryan et al. (2012) and Warwick et al. (2005) identified $U$ sorption to carboxylic and phenolic functional groups on insoluble humics and fulvics as the likely scavenging mechanism. Furthermore, $U$ accumulation in peat and other OM-rich environments is commonly conceptualised as involving initial U(VI) adsorption followed by reduction to $U(I V)$, with the latter process resulting in long-term $U$ immobilisation (Spirakis, 1996). A suite of factors may facilitate $U$ reduction in sediments, including increased temperature (Nakashima 1992), electron donors such as $\mathrm{H}_{2} \mathrm{~S}$ or $\mathrm{Fe}^{2+}$, and direct enzymatic reduction (Newsome et al., 2014; Campbell et al., 2015). Mineral surfaces (e.g., pyrite; Fe-Ti-oxides) and insoluble OM may also play roles in reduction of sorbed $\mathrm{U}(\mathrm{VI})$, 
catalysing rate-limiting reaction steps by facilitating electron transfer from underlying material or co-adsorbates (Renock et al., 2013; Latta et al., 2014). Most U in fossil economic U deposits, including OM-rich types (Min et al., 2000; Deditius et al., 2008), has been assumed to be associated with U(IV)-minerals, such as coffinite, or other non-crystalline forms (Bhattacharyya et al., 2017). Interestingly, synchrotron X-ray absorption spectroscopy (XAS) data have revealed the presence of both $U(I V)$ and $U(V I)$ in some OM-rich $U$ deposits, with U(IV) constituting of 35-68\% of total U (Mikutta et al., 2016). Regenspurg et al. (2010) found a mixture of $U(V I)$ and $U(I V)$ in alpine soils from the Dischma Valley (Switzerland), based on combined carbonate extractions and data from X-ray Absorption Near Edge Structure (XANES) analyses. These results point to $\mathrm{U}(\mathrm{VI})$ being an important component of $\mathrm{U}$ bound to $\mathrm{OM}$ surfaces. From these recent findings, a picture is emerging for $\mathrm{U}-\mathrm{OM}$ association in modern sediments that emphasizes the complexity and variability of $U$ redox state and chemical speciation (Mikutta et al., 2016; Bone et al., 2017).

Synchrotron $\mathrm{x}$-ray absorption spectroscopy (XAS) provides a suitable analytical technique for obtaining U-oxidation state and speciation in OM-rich sediments, since it is sensitive to both 'invisible' (e.g., colloidal; adsorbed; associated with OM, typically sub > $10 \mathrm{~nm}$ ) and mineralbound U (Denecke et al., 1998a; Denecke et al., 1998b; Mikutta et al., 2016; Bhattacharyya et al., 2017). XAS can be applied to samples with a complex composition and containing a wide range of $U$ concentrations (from a few ppm to wt.\%). Here our objective was to characterise the physical and chemical nature of $U$ within an OM-rich Eocene sedimentary $U$ deposit, Mulga Rock (Western Australia), in order to determine the relative abundance and origins of observed $\mathrm{U}(\mathrm{IV})$ or $\mathrm{U}(\mathrm{VI})$. Our results inform strategies for sustainable mining 
92 (subsurface extraction) or environmental remediation of $U$ in OM-rich sedimentary or

93 aqueous environments.

\section{Geological setting and core sampling}

95 The Mulga Rock (MR) U deposit is located near Kalgoorlie (Western Australia; Figure 1),

96 hosted within a series of paleochannels and lacustrine beds formed during the Eocene (56-

$9734 \mathrm{Ma})$, now buried to shallow depths (30 to $50 \mathrm{~m}$ ). According to the petrographic analyses

98 of Jaraula et al. (2015), MR sediments contain a mixture of particulate and non-particulate

99 OM consisting of woody (lignite) material combined with aquatic algal and bacterial

100 biomass, consistent with accumulation from a combination of forested, wetland and

101 lacustrine environments. Over time, the OM layers and deeper sediments became anoxic,

102 with considerable evidence for microbial production of authigenic minerals, most

103 prominently Fe-sulphides. Uranium accumulation likely resulted from groundwater flow

104 through permeable sandstones within palaeochannels, and scavenging of the carried $U$

105 (present day average $8 \mu \mathrm{g} \mathrm{L}^{-1} \mathrm{U}$ in local groundwater) by OM-rich layers (Douglas et al.,

106 2011; Jaraula et al., 2015). U-Pb isotope systematics and U-Th disequilibria studies suggest

107 that $U$ and the associated metals originated from local lamproitic or carbonatitic sources

108 (Douglas et al., 2011; Jaraula et al., 2015). 
110



111 Figure 1. Map of Mulga Rock, deposit sites, core locations and detail from core 5613 112 showing lithology, oxidation state and radioactivity (obtained from down-hole gamma log 113 counts (Vimy, 2014)). See also SI Table 1 for locations.

114 To date, four orebodies with potential $U$ resources have been delineated at MR:

115 Ambassador, Emperor, Princess and Shogun (Figure 1). Ambassador, discovered in 1979, has

116 been the main subject of industry and academic investigations, with resources estimated at

117 13,000 tonnes U (Douglas et al., 1993; Douglas et al., 2011). The most recent orebody,

118 Princess, was discovered in March 2012. The wider MR deposit is estimated to contain $11966.5 \mathrm{MT}$ of ore at $520 \mathrm{mg} \mathrm{kg}^{-1} \mathrm{U}_{3} \mathrm{O}_{8}$ (Vimy, 2016c). The geological setting and close 120 association of $U$ with OM-rich sediments at MR make it an excellent site for studying the nature of $U$ in ore-grade OM-rich environments. 
We analysed 18 samples from nine air- and diamond-drilled cores obtained from the March 2012 drilling project: Ambassador (4), Emperor (1), Princess (3) and Shogun (1), together with a section of lignite (CD 1577) extracted during a previous exploration campaign from the Ambassador deposit (Vimy, 2014, 2015, 2016a, b). Lignite sample CD 1577 was immediately preserved in epoxy resin to prevent oxidation. The March 2012 samples were selected on-site as they were extracted (sample locations given in Error! Reference source not found.) and immediately stored in airtight containers, taking care to minimize exposure to air and to leave no air gap. The samples were selected to represent a range of redox states, mineralisation types and grades, as estimated on-site by a handheld Niton XL3t X-ray Fluorescence (XRF) spectrometer, and on the radiometrics determined using a down-hole gamma probe (AusLog, \#T125, 33mm diameter) calibrated with a $\mathrm{Cs}^{137}$ source (Vimy, 2014, 2016b). Laboratory based geochemical analysis was completed 6-12 months after sampling and preservation; synchrotron X-ray analysis was performed within two years of sample preservation.

\section{Geochemical Analysis}

137 Six analytical methods were used: bulk core sample analysis (ICP-MS); chemical extractions

138 (ICP-MS); electron microscopy; and synchrotron-based XAS and X-ray fluorescence 139 microscopy (XFM).

\subsection{Sample preparation and measurements of loss on ignition (LOI) and pH}

141 Samples were characterised using fresh, oven-dried, ashed or dried-homogenised material.

142 To obtain dry masses, sub-samples and replicates were oven-dried at least overnight at $143104{ }^{\circ} \mathrm{C}$ and weighed until constant mass. The resulting oven-dried samples either underwent

144 LOI analysis, or were homogenised to a very fine powder in an agate-lined ball mill and dry- 
stored in glass vials at ambient temperatures until further analysis. The LOI analysis was undertaken on a subset of samples (replicates $=5, \mathrm{n}=12$ ) at $550{ }^{\circ} \mathrm{C}$ for $4 \mathrm{hr}$, then $900{ }^{\circ} \mathrm{C}$ for

$1472 \mathrm{hr}$, using a Thermoline muffle furnace (Dean, 1974; Heiri et al., 2001). A reduced number of samples were analysed for LOI (12 of 18) to conserve material. Powdered samples were analysed for total nitrogen (TN), organic carbon (TOC) and sulphur (TS) by an Elementar III analysed within 3 months of sample recovery using the method of (Rowell, 1994). Measurements were conducted on duplicate samples using a Thermo portable meter with standard calomel electrode. Six grams of undried sample was mixed with $15 \mathrm{ml}$ of water, the slurry was shaken by hand for 15 minutes, and the $\mathrm{pH}$ was then measured immediately and again after 10 minutes.

\subsection{Total and extractable metals including $U$}

157 Total metals, $U$ and rare earth elements (REE) concentrations were obtained from aciddigested samples using a method adopted from Kamber et al. (2003) and Eggins et al. (1997). Both dried and ashed samples were analysed for $U$ (SI Table 5). $2 \mathrm{~mL}$ of tripledistilled $\mathrm{HF}$ and $1 \mathrm{~mL}$ triple-distilled $\mathrm{HNO}_{3}$ were added to $100 \mathrm{mg}$ of sample in capped Teflon vessels and digested at $135{ }^{\circ} \mathrm{C}$ overnight on a hotplate. The dehydrated material was refluxed twice with concentrated $\mathrm{HNO}_{3}$, then dissolved overnight in $3 \mathrm{~N} \mathrm{HNO}_{3}$. The solutions were transferred to transparent polycarbonate tubes, and diluted with water. Solutions were diluted further to a factor of 5000 with a solution of $1.6 \% \mathrm{HNO}_{3}$, then analysed using inductively coupled plasma-mass spectrometry (quadrupole ICP-MS, Agilent 7700x). Results of digested samples are reported as $\mathrm{mg} \mathrm{kg}^{-1}$ of dry mass. There was a significant correlation $\left(R^{2}=0.999, p<0.005\right)$ between the ashed $(n=12)$ and unashed samples, indicating confidence in that the organic matrix did not interfere with the ICP-MS analysis. 

were undertaken to further constrain $U$ speciation and oxidation state on 18 sub-samples.

171 Typically, bi-carbonate extraction assumes that in the absence of oxygen, $\mathrm{U}(\mathrm{VI})$ forms strong complexes with carbonate ions and hence becomes highly soluble, whereas $U(I V)$, including

173 unoxidised biogenic U(IV), remains uncomplexed and insoluble (Guillaumont et al., 2003;

174 Zhou and Gu, 2005). In some circumstances, monomeric (i.e., sorbed) biogenic U(IV) can be 175 released in concentrated bicarbonate solutions, without affecting uraninite/coffinite 176 stability (Alessi et al., 2012). Thus in our work the extracted U(VI) may also contain a small

177 fraction of mobile, highly reactive biogenic $\mathrm{U}(\mathrm{IV})$. The dissolved $\mathrm{U}(\mathrm{VI})$ can be separated by 178 filtration (i.e. $0.2 \mu \mathrm{m}$ ) of the aqueous phase, and the $U(I V)$ concentration can be estimated 179 by subtraction of the amount of soluble $U$ analysed by ICP-MS from the total $U$ value. This 180 provides a minimum $\mathrm{U}(\mathrm{VI})$ concentration, since some $\mathrm{U}(\mathrm{VI})$ minerals, in particular silicates, phosphates and vanadates are sparingly soluble (Tokunaga et al., 2012; Kanematsu et al., 2014; Mehta et al., 2014). Bi-carbonate extractions were performed in duplicate under anaerobic $\left(\mathrm{N}_{2}\right)$ conditions as follows: $20 \mathrm{ml}$ of $1 \mathrm{M} \mathrm{NaHCO}_{3}$ (de-gassed) was added to $\sim 1.7 \mathrm{~g}$ fresh hand-ground sediment; $\mathrm{pH}$ was recorded; and the sample was placed in $100 \mathrm{~mL}$ crimped and sealed serum bottles (acid washed, $10 \% \mathrm{HNO}_{3}$ ) with the headspace replaced with $\mathrm{N}_{2}$ gas to avoid oxidation. Blanks were prepared as above. The suspensions were rotated on an orbital shaker $\left(150 \mathrm{rpm}, 25^{\circ} \mathrm{C}\right)$ continuously for one week, and then settled

188 for 10 minutes, after which they were vacuum-filtered through $0.2 \mu \mathrm{m}$ cellulose nitrate 189 membranes (Whatman). Filtration was generally fast, with additional filters used where necessary. Filtrate solutions were acidified $\left(1 \% \mathrm{HNO}_{3}\right)$ and then analysed by ICP-MS. The $\mathrm{pH}$ of the bi-carbonate/sediment suspension was $8.5 \pm 0.1$. Water extractions were performed 
under the same conditions but filtered using a standard $1.2 \mu \mathrm{m} \mathrm{GF/C} \mathrm{Whatman} \mathrm{glass} \mathrm{filter}$ paper to include a potentially mobile U colloidal fraction.

\subsection{Imaging $U$ distribution and elemental association using XFM and SEM}

195 To determine the microscale spatial distribution and elemental/mineralogical association of U, subsamples of unground grains from core NNA 5613 (Ambassador ore body) were

197 selected based on total activity (measured by Geiger counter) and mounted onto $0.5 \mathrm{~cm}^{2}$ SiN windows using a $5 \%$ glucose solution. Due to the finely dispersed nature of the $U$ in the MR samples, TEM techniques proved unsuccessful in detecting $U$ in the samples. One sample, MR5613a, yielded better SEM results and gave higher radioactive counts per second, likely due to higher $U\left(5000 \mathrm{mg} \mathrm{kg}^{-1}\right)$ concentrations. This sample was therefore favoured for subsequent micro-analytical characterisation.

Subsample grains from MR5613a were analysed at the XFM Beamline (Australian Synchrotron) at $18.5 \mathrm{keV}$ incident photon energy and $2 \mu \mathrm{m}$ beam size (Paterson et al., 2011). Fluorescence signals were collected using a 384-pixel Maia detector (Ryan et al., 2014). The fluorescence spectra collected were processed using the GeoPIXE software to

207 produce semi-quantitative elemental maps (Ryan and Jamieson, 1993; Ryan, 2000; Etschmann et al., 2010; Li et al., 2016).

210 sections using a Philips FEI XL30 environmental scanning electron microscope (ESEM) equipped with an OXFORD INCA energy-dispersive X-ray spectrometer (EDS) (Earth Sciences,

212 University of Melbourne), and EDS maps were collected with a Field Emission Philips XL30 ESEM (BIO21, University of Melbourne). 
214 The mineralogy of lignite sample CD 1577 was characterised using $\mu$-XRD. Spectra were 215 collected using a Bruker general area detector diffraction system (GADDS) with $\mathrm{Cu} \mathrm{K}_{\alpha}$ 216 radiation and 200 or $300 \mu \mathrm{m}$ collimators (CSIRO, Clayton, Melbourne; SI Figure 1).

\section{$217 \quad 3.4 \quad$ Uranium speciation via XANES and EXAFS spectroscopy.}

218 X-ray absorption near edge structure (XANES) and extended x-ray absorption fine structure

219 (EXAFS) spectra were collected at the $\mathrm{U}-\mathrm{L}_{3}$ absorption edge at the XAS Beamline (Australian Synchrotron). Spectra were collected for eight powdered core samples (MR5076a, MR5076b, MR5077, MR5613a, MR5613b, MR5766b, MR5766c, MR5766d,) selected because they had sufficient $U$ concentrations (from ICP-MS results) to yield good quality spectra, and nine U-bearing minerals provided by the Melbourne Museum serving as standards. Data on these standards are presented in the supplementary information (Error! Reference source not found., SI Figure 2 and SI Figure 3). Homogenised powdered samples or mineral standards diluted with boron nitride were packed into Al holders, and sealed with Kapton tape. For analysis, samples were loaded into a He cryostat (pulse-tube Optistat, Oxford Instruments; $\mathrm{T}^{\sim 10 K)}$. In addition, spectra were taken from a fresh section of the core subsample CD 1577 at six random points. The incident energy was controlled using a Si(111) double crystal monochronomator and calibrated at the $\mathrm{Zr}-\mathrm{K}$ absorption edge using a $\mathrm{Zr}$ metal foil (first maximum of the first derivative at $17998 \mathrm{eV}$ ). Repeat measurements of this $\mathrm{Zr}$ foil established that there was no measurable energy shift during the experiments. Uranium was detected concurrently in fluorescence (100 element Canberra HP-Ge fluorescence detector) and transmission modes using ion chambers (Oken, $\mathrm{N}_{2}$ flow at $\sim 0.3$ $\mathrm{L} / \mathrm{min}, \mathrm{U}=2.1 \mathrm{kV}$ ). Aluminium foil was used to reduce parasitic fluorescence count rate from other fluorescence. Radiation induced changes to $U$ valence or chemistry, assessed over repeat XANES runs, were negligible. The XANES scans were acquired as follows: baseline, 
with constant steps in k-space $\left(\delta k=0.035 \AA^{-1}\right)$ above the edge. For EXAFS measurements the energy range was extended to $\sim 18140 \mathrm{eV}\left(k^{\sim} 16 \mathrm{~A}^{-1}\right)$.

Spectra normalisation and linear combination fitting (LCF) were performed using the DEMETER software package (Ravel and Newville, 2005). Most spectra were truncated after $17969 \mathrm{eV}\left(14 \AA^{-1}\right)$ to avoid interference from the ZrK edge. The LCF was performed using two reference spectra, synthetic uraninite for U(IV) (Tsarev et al., 2016) and uranopilite for $\mathrm{U}(\mathrm{VI})$ (see also SI Figure 2 ). The uranium oxidation state was determined from the LCF data.

The EXAFS data were processed and refined using the HORAE package (Ravel and Newville, 2005) with the theoretical standards calculated by FEFF9 (Rehr et al., 2010). The $k^{n}$ weighted data $(\mathrm{n}=1,2,3)$ were refined in $R$ space. The amplitude-reduction factor $\left(\mathrm{S}_{0}{ }^{2}\right)$ was estimated to be 0.85 by fitting $\mathrm{UO}_{2}\left(\mathrm{NO}_{3}\right)_{2} \bullet 6 \mathrm{H}_{2} \mathrm{O}$ (structure confirmed by powder XRD; $\mathrm{SI}$ Table 3 and Error! Reference source not found.); this value was used in the refinement of all the sample data.

\section{Results}

\subsection{Core geochemistry}

254 Core sample appearance varied from sandy and dry, to dark, peaty and moist, with a mean moisture content of $\sim 12$ wt. \% (range 0.3 to 38 wt. \%). Mean sample pH was 4.5 (range 3.5 to 7). The physicochemical data are presented in SI Table 4. The TOC concentrations of the

257 samples averaged 22.5 wt. \% (range 1 to 59 wt. \%), reflecting substantial vertical in situ variation in the MR deposit. Samples $\mathrm{LOI}_{550}$ ranged from 1 to $57 \mathrm{wt}$ \%, and correlated with TOC $\left(R^{2}=0.922\right.$, slope $\left.=1.04, p<0.005 ; n=10\right)$. Further LOI performed at $900{ }^{\circ} \mathrm{C}\left(\mathrm{LO}_{900}\right)$ 
ranged from 1 to 78.3 wt. \% (average = 31 wt. \%). This mass loss between 550 and $900{ }^{\circ} \mathrm{C}$

261 can be attributed to decomposition of inorganic carbonates (Dean, 1974; Heiri et al., 2001). 



Figure 2. Uranium distribution and correlations with organic matter and trace elements. (A) Bar chart showing uranium distribution in samples according to carbon content. The data $(n=18)$ are split on the basis of their carbon contents (TOC) into two equal groups ( $n=9$ for each group); one group has < 21 wt. \% TOC, the other 22-60 wt. \% TOC. Error bars are standard deviations of uranium concentration: samples containing $<21 \%$ TOC contain $1600 \mathrm{mg} \mathrm{U} \mathrm{kg}^{-1}$ and those with 22-60 wt. \% TOC $4500 \mathrm{mg} \mathrm{U} \mathrm{kg}^{-1}$. (B) Pearson correlation coefficients for all core samples $(n=18) ;(B-1)$ between TOC and metals; and (B-2) $U$ and metals, where height of bar corresponds to $R^{2}$ values. Stars indicate statistical significance: *** $p<0.005$; ** $p<0.05 ; * p<0.5$, ns (no star) $p>0.51$. Note that Fe was not analysed in these samples. (C and D) Detail of sediment grains from the MR core NNA 5613: (C1) Scanning Electron Microscope (SEM) image; (C-2) is enlargement of (C-1), showing U-rich and $\mathrm{Zn}$-rich particles of similar sizes. (D) Synchrotron $\mathrm{x}$-ray fluorescence (XFM) image showing $\mathrm{U}, \mathrm{Cu}$ and $\mathrm{Sr}$ distribution in representative grain from the same sample as (C); $U=$

279 [full colour figure in print ] 
Uranium in the core samples ranged from 2 to $15,000 \mathrm{mg} \mathrm{kg}^{-1} \mathrm{U}$ (mean $=2800 \mathrm{mg} \mathrm{kg}^{-1}, \mathrm{n}=$ 18), and correlated with chemical digests performed on ashed samples $\left(900{ }^{\circ} \mathrm{C}, \mathrm{n}=12\right.$ ) when normalised to $\mathrm{mg} \mathrm{kg}^{-1}$ dry mass $\left(\mathrm{R}^{2}=0.998\right.$, slope $=1.00, \mathrm{p}<0.0005$; Pearson) (see $\mathrm{SI}$ Table 5). Core samples contained average element concentrations in the order $\mathrm{Ti}>\mathrm{U}>\mathrm{Zn}>\mathrm{Ca}>$ total $\mathrm{REE}>\mathrm{Cu}>\mathrm{Ni}>\mathrm{Pb}>\mathrm{Cr}>\mathrm{Co}>\mathrm{Sc}>\mathrm{V}>\mathrm{As}>\mathrm{Th}$ (SI Table 6). Correlations between $\mathrm{U}$ and TOC, and $U$ and other metals were weak $(p<0.5)$, with the strongest relationships occurring between $U$ and $\mathrm{Pb}, \mathrm{U}$ and total REEs, $\mathrm{Cd}$ and $\mathrm{As}\left(\mathrm{p}<0.005, \mathrm{R}^{2}\right.$ values shown in Figure $2 \mathrm{~B}$ and SI Table 7). Slight correlations were observed between TOC and $\mathrm{Ca}$, Sr or V ( $<0.05$ ), but most elements show no significant correlation with TOC. Detailed analyses on the organic chemistry of samples from the Mulga Rock deposit are presented elsewhere (Jaraula et al 2015).

The spatial distribution of $U$ in the core samples was highly variable, with $U$ present either in diffuse form (no identifiable minerals $>10 \mathrm{~nm}$ ) or as U-rich micro- to nano- particles (see XFM and SEM images in Figure 2 C and D). Sample MR5613a (from core NNA 5613, Figure 2 D), with a bulk $U$ concentration of $5,000 \mathrm{mg} \mathrm{kg}^{-1}$, showed substantial variation in the form and distribution of $U$ between the four subsamples scanned. Two subsamples contained disseminated $U$, while $U$ was present as discrete $\mu \mathrm{m}$-sized particles in the other two. The lignite sample CD 1577 was structurally more coherent than the March 2012 cores. The mineral matrix consisted mainly of quartz (see Error! Reference source not found. for $\mu$ XRD analysis). SEM elemental mapping and BSE imaging (Figures 3, 4 and SI Figure 4 for EDS spectrum) show that $U$ exists in particulate form ( $\mu \mathrm{m}$-sized), but also forms large (up to $>1 \mathrm{~mm}$ ) aggregates around Fe-sulfide minerals. The U-pyrite association is common at MR (Douglas et al., (2011) as well as in many sandstone-hosted U deposits (e.g., Bonnetti et al. 
304 (2015; 2017); Wülser et al., (2011)), and probably reflects an association between bacterial 305 sulphate reduction and $U$ reduction (Bonnetti et al., 2017). Micro-XRD data confirm the 306 predominance of pyrite, and show that the main U-phase surrounding the pyrite 307 grains/aggregates is coffinite $\left[\mathrm{USiO}_{4}\right]$ (Error! Reference source not found.). The MR coffinite 308 has unit cell parameters $\left(a=b=6.943(2) \AA ; c=6.262(2) \AA\right.$; $\left.V=301.9(3) \AA^{3}\right)$ that are close to 309 those of the Tertiary sandstone hosted Beverly deposit in South Australia $(a=b=6.971(2) \AA$; $310 \quad c=6.255(2) \AA ; \quad V=304.0(3) \AA^{3}$; Wülser et al. (2011)).
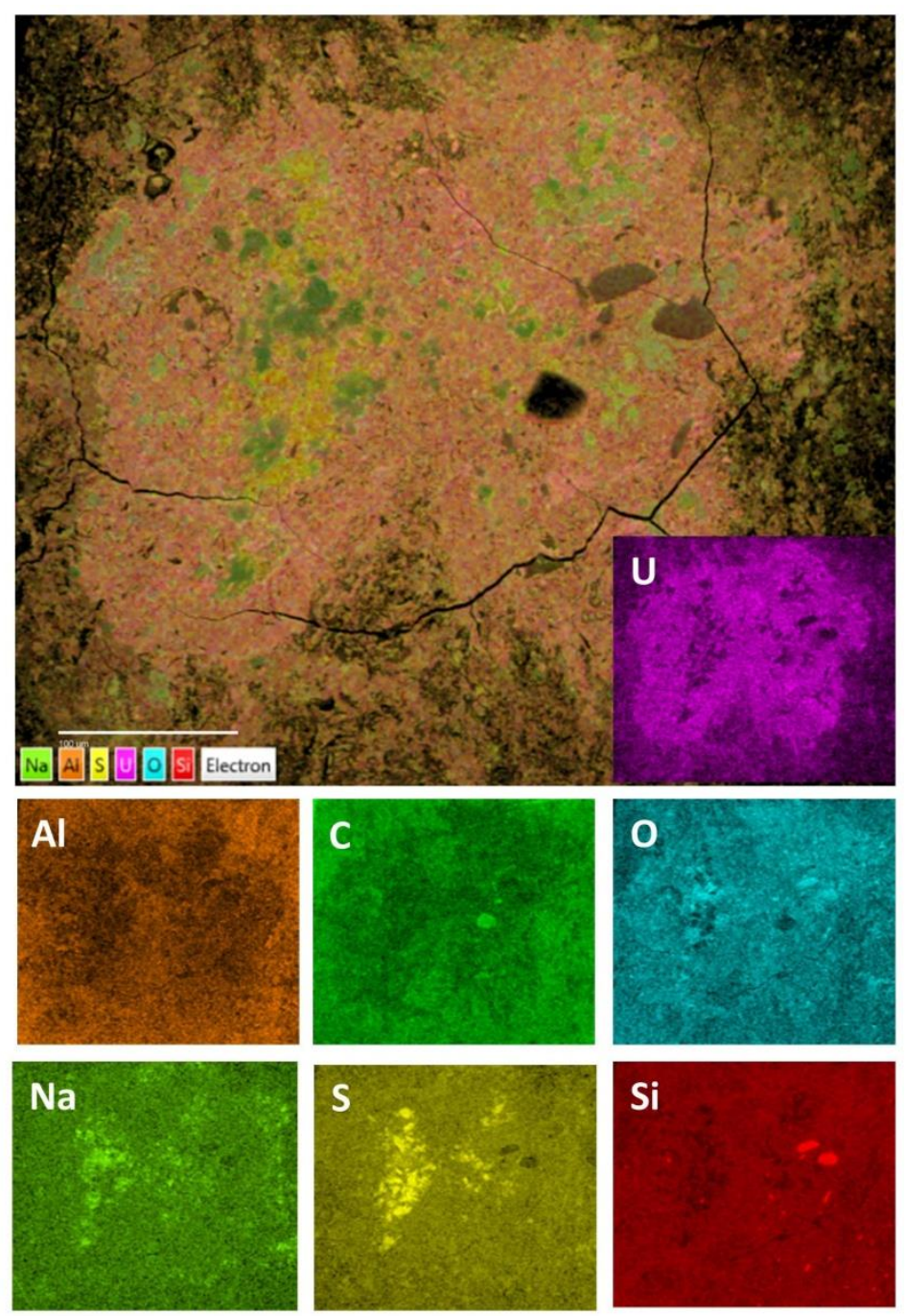

312 Figure 3. Chemical maps ( $\mathrm{U}, \mathrm{Al}, \mathrm{C}, \mathrm{O}, \mathrm{Na}, \mathrm{S}$ and $\mathrm{Si}$ ) based on SEM-Energy Dispersive 313 Spectrometry (EDS) of lignite sample CD 1577. Elemental concentrations are represented by 314 intensity, where bright colours show high concentrations and dark or black areas represent areas where elements are absent or at low concentrations. Sulfur corresponds to pyrite 
distribution. $\mathrm{Si}$ is associated with $\mathrm{U}$ (coffinite according to XRD results), bright spots

317 correspond to quartz. Scale bar is $100 \mu \mathrm{m}$.

318 [full colour figure in print]

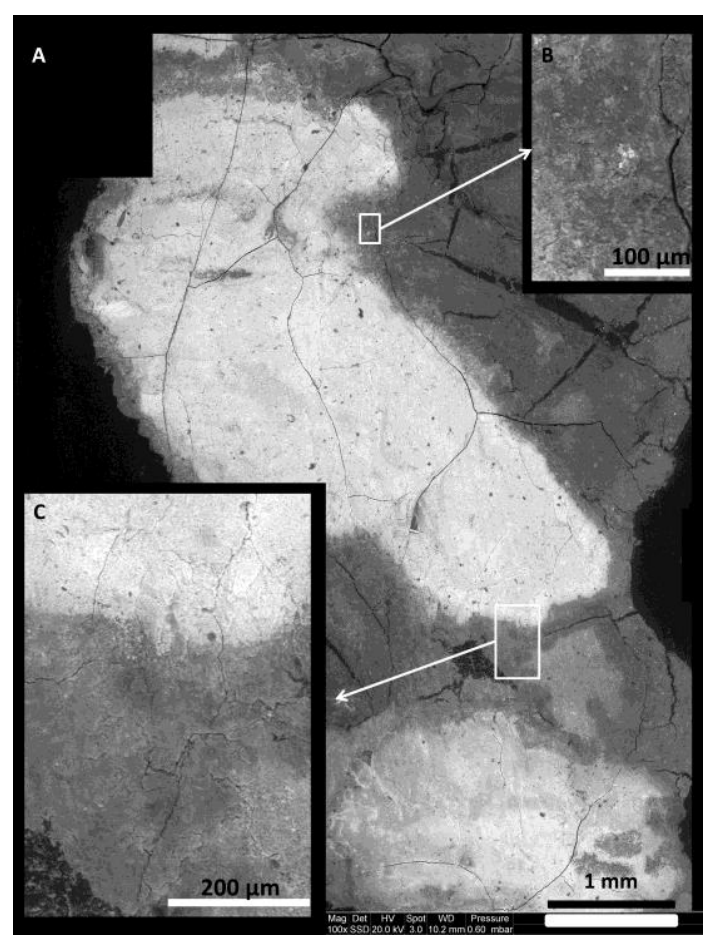

Figure 4. Composite ESEM backscatter image, showing distribution of uranium in the lignite section from core CD 1577. Uranium is present throughout the whole sample with the brightest phase illustrating the highest $U$ concentration. The EXAFS spectra were taken at random points which showed that $U$ was present in both $U(I V)$ and $U(V I)$ oxidation states across the sample. Inserts (B) and (C) are enlargements of indicated areas in (A).

\subsection{Leach tests and XANES linear combination fits}

In all samples analysed, $U$ was present in both $U(I V)$ and $U(V I)$ oxidation states, with usually more $U(V I)$ than $U(I V)$. Bicarbonate extraction of $U\left(U_{\mathrm{CO} 3}\right)$, a process conducted under anaerobic $\left(\mathrm{N}_{2}\right)$ conditions which targets leachable $\mathrm{U}(\mathrm{VI})$ ions, indicated that an average of $69 \%(S D= \pm 18, n=18)$ of total $U$ is in the $U(V I)$ form. The oxidation state of $U(U(I V)$ or $U(V I))$ and total concentrations of $U$ are highly correlated $\left(R^{2}=0.996, p<0.005\right)$ with the percentage of $U(V I)$ increasing with total $U$ concentration, giving a slope of 0.79 for $U(V I)$ versus total $U$ (Figure $5 A)$. Figure 5B shows that samples with low TOC $(<8 \%)$ have a highly 
336 relatively constant oxidation state, dominated by $\mathrm{U}(\mathrm{VI})(75 \pm 7 \% \mathrm{U}(\mathrm{VI}))$. Interestingly, 337 extractions using only deionised (ultra-pure, 18.2 M $\Omega$ ) water under the same anaerobic 338 conditions as bi-carbonate method, only removed $2.5 \%$ of the total $U$, showing that the 339 majority of $U$ was not readily water-soluble.

340 The $U$ oxidation state $\left(U_{\mathrm{XAS}}\right)$ was independently derived from the LCF results as described

341 above (see also Error! Reference source not found. and Figure 5 C and D for the normalized

342 XANES spectra). The LCF data (Error! Reference source not found.) show that the uranium is

343 predominately present (i.e. $74 \%$ ) in the higher oxidation state, +6 . These results are

344 consistent with the concentration values from $\mathrm{CO}_{3}$-extraction. Comparison of XAS (74\%) and

345 bi-carbonate extraction datasets (69\%) showed good agreement, giving an overall mean 346 across the two methods of $71 \% \mathrm{U}(\mathrm{VI})$. 

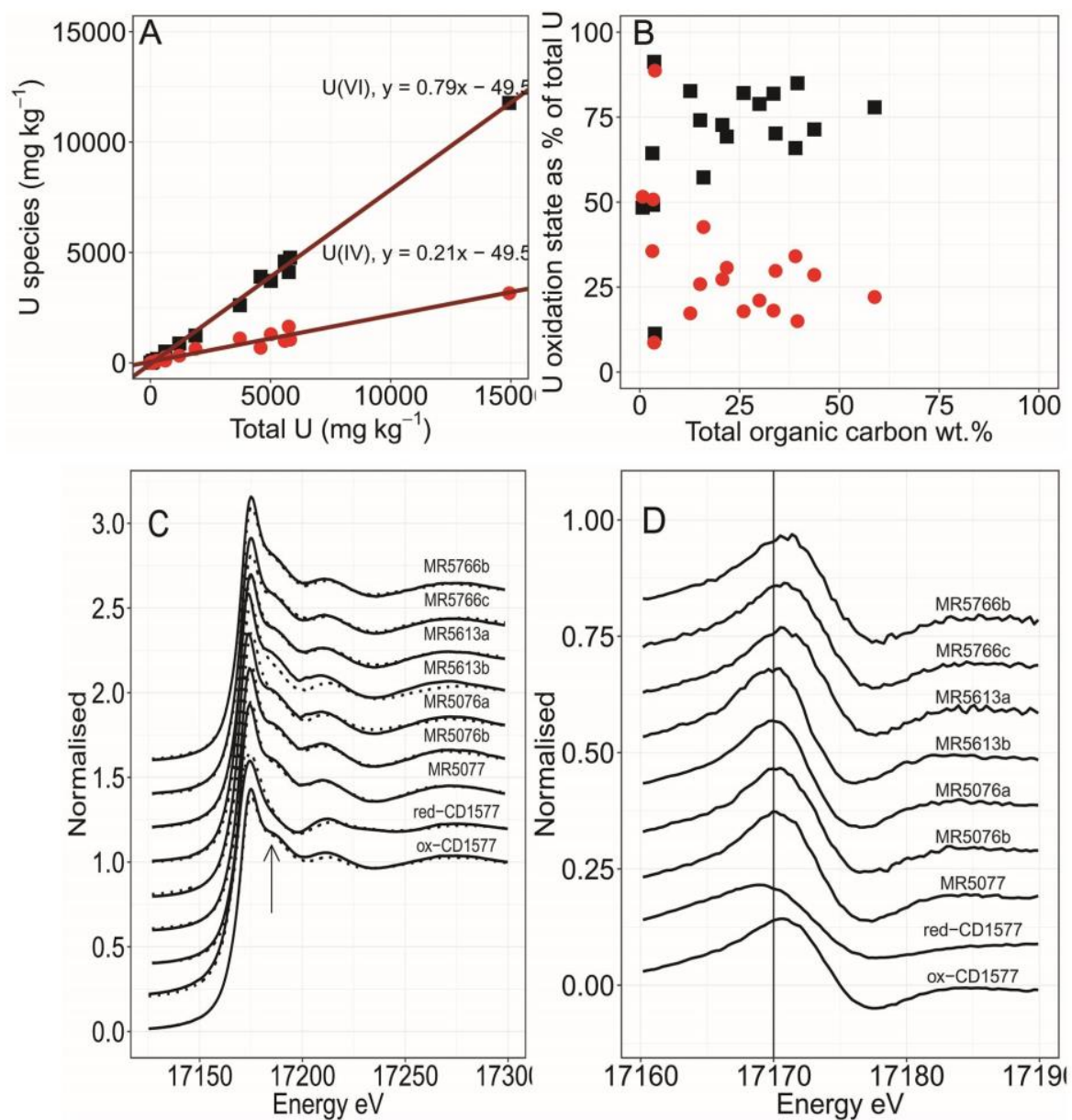

349 Figure 5. Uranium speciation as derived from bicarbonate extraction ( $A$ and $B$ ); and 350 synchrotron-XANES analyses (C and D). (A) Bi-carbonate extracted $U(V I)$ and $U(I V)$ data in $351 \mathrm{mg} \mathrm{kg}^{-1}$ (y axis) plotted as a function of total $\mathrm{U}\left(\mathrm{mg} \mathrm{kg}^{-1}\right)$. Black squares are $\mathrm{U}(\mathrm{VI})\left(\mathrm{R}^{2}=0.996\right.$. $y=0.7896 x-49.5$ for $U(V I))$ and red dots are $U(I V)\left(R^{2}=0.21 \times 49.5\right)$. (B) $U(I V)$ and $U(V I)$ oxidation states as percent of total $\mathrm{U}(\mathrm{U}(\mathrm{VI}) /(\mathrm{U}(\mathrm{VI})+\mathrm{U}(\mathrm{IV})) \times 100$ plotted as a function of TOC wt. \%. Black squares $=\mathrm{U}(\mathrm{VI})$, and red dots $=\mathrm{U}(\mathrm{IV})$. (C) XAS-XANES spectra of MR bulk core samples and the lignite sample CD1577. The overlain dotted line is the fitted spectra from LCF The arrow marks the position of the $\mathrm{O}=\mathrm{U}=\mathrm{O} \mathrm{U}(\mathrm{VI})$ shoulder. (D) are the derivatives of (C).

\subsection{EXAFS fits}

360 Two types of XANES spectra were obtained from six measurements performed on the lignite

361 sample CD 1577 (Figure 4). These spectra were grouped, merged and analysed separately, with one type showing a uranyl-like ('oxidised-CD1577') spectrum and the other a reduced 

types (Figure 6), and different fitting strategies were used for each type. EXAFS data from the samples MR5766c and MR5613a are similar to the 'oxidised-CD1577' lignite spectra, and were refined simultaneously.

\subsubsection{Fitting of the EXAFS spectra with uranyl-like XANES}

EXAFS spectra from MR5766c, MR5613a and 'oxidised-CD1577' were analysed with a common $E_{0}$, using selected paths from the uranopilite structure (amcsd 0005730; Burns (2001)), and one uranium-carbon single-scattering path from the structure of $\mathrm{C}_{15} \mathrm{H}_{10} \mathrm{O}_{8} \mathrm{U}$ from de Lill and Chan (2013). The advantage of this approach is that the 'oxidised-CD1577' spectra could be fitted by constraining the distances and Debye-Waller factors to be the same as those for MR5766c. To obtain the best fit for the 'oxidised-CD1577' spectra, the number of oxygen atoms (O15 only) was refined, allowing additional oxygen to be fitted that was not present in the MR5766c and MR5613a spectra. Note that the choice of C rather than another light element (e.g. O, N, P) cannot be justified by EXAFS alone. Carbon was chosen because the refined bond-distance and coordination are consistent with previous studies (see below); SEM did not reveal a correlation between $U$ and $P$, or any of the poorly soluble uranyl phosphates minerals; and the samples are rich in $C$ but poor in $N(C / N \geq 100$; Jaraula et al. 2015). The final results are shown in Table 1.

Two models were used for comparison: a simple model where the two equally short U-O distances (uranyl ion) were constrained to be the same (Table 1); and a second model where the two short U-O distances were refined independently (SI Table 9). While more complex multiple scattering (MS) paths $\left(\mathrm{U}-\mathrm{O}_{\mathrm{ax2}}-\mathrm{U}-\mathrm{O}_{\mathrm{ax2}}, \mathrm{U}-\mathrm{O}_{\mathrm{ax2}}-\mathrm{O}_{\mathrm{ax} 1}\right.$ and $\left.\mathrm{U}-\mathrm{O}_{\mathrm{ax2}}-\mathrm{U}-\mathrm{O}_{\mathrm{ax} 1}\right)$ could be employed to fit the data out to a distance of $3.58 \AA$ in the second model, the two short U-O 
386 bonds were the same within error (1.75(3) and 1.77(3) Å). Furthermore, the goodness-of-fit 387 parameters for both models were effectively identical, indicating that there was no 388 significant advantage to the second model, so that the simpler model (Table 1 ) is preferred.

389 In all cases, the fit resulted in two carbon atoms at distances of $2.90(7)$ to $2.93(3) \AA$. This 390 configuration suggests a bidentate coordination to functional groups of the solid OM. All $391 \mathrm{U}(\mathrm{VI})$-dominant spectra lacked a peak at distance of $3.8 \AA$, which would indicate the 392 presence of $U-U$ bonds. This shows that most $U$ is not present in the form of uranyl 393 minerals. Consequently, the most $\mathrm{U}(\mathrm{VI})$ in the studied samples is present predominantly as a 394 monomeric $\mathrm{U}(\mathrm{VI})$ complex bound to $\mathrm{OM}$. This is further supported by the flattening of the 395 oscillation between 6.8 and $7.9 \AA^{-1}$ in the $k^{2}$-weighted EXAFS data (arrow, Figure 6A), a 396 feature which appears in uranyl-humic compounds (Denecke et al., 1998a; Denecke et al., 397 1998b; Mikutta et al., 2016). 




\begin{tabular}{|c|c|c|c|c|c|c|c|c|c|c|c|c|c|}
\hline sample & ligand & $\mathbf{N}$ & $R(A)$ & ss $\left(A^{2}\right)$ & fraction & $\begin{array}{c}\mathbf{N}_{\text {tot }}= \\
\mathbf{N}^{*} \text { fraction }\end{array}$ & $\Delta \mathrm{E}_{0}$ & $\operatorname{red} X^{2}$ & $r$-factor & $\begin{array}{c}\text { k-range } \\
\left(\AA^{-1}\right)\end{array}$ & R-range (A) & k-weighting & $\mathrm{SO}^{2}$ \\
\hline \multirow{6}{*}{ MR5766c } & Oax2 & 2 & $1.773(5)$ & 0.003 (fix) & & & $9.2(5)$ & 113 & 0.023 & $2-12$ & $1.3-4$ & $1,2,3$ & 0.85 \\
\hline & 015 & 2 & $2.22(1)$ & 0.003 (fix) & & & & & & & & & \\
\hline & 014 & 2 & $2.36(1)$ & 0.003 (fix) & & & & & & & & & \\
\hline & $\mathrm{OH} 20$ & 2 & $2.42(2)$ & 0.003 (fix) & & & & & & & & & \\
\hline & C & 2 & $2.93(3)$ & 0.003 (fix) & & & & & & & & & \\
\hline & U-Oax2-U-Oax2 (MS) & & $3.545(7)$ & 0.006 (fix) & & & & & & & & & \\
\hline \multirow{6}{*}{ MR5613a } & Oax2 & 2 & $1.77(2)$ & 0.003 (fix) & & & $11(3)$ & 113 & & $3-11.5$ & $1.3-4$ & $1,2,3$ & 0.85 \\
\hline & 015 & 2 & $2.24(4)$ & 0.003 (fix) & & & & & & & & & \\
\hline & 014 & 2 & $2.39(4)$ & 0.003 (fix) & & & & & & & & & \\
\hline & $\mathrm{OH} 20$ & 2 & $2.45(6)$ & 0.003 (fix) & & & & & & & & & \\
\hline & C & 2 & $2.90(7)$ & 0.003 (fix) & & & & & & & & & \\
\hline & U-Oax2-U-Oax2 (MS) & & $3.55(3)$ & 0.006 (fix) & & & & & & & & & \\
\hline \multirow[t]{6}{*}{ oxidised-CD1577* } & Oax2 & $2.3(2)$ & $1.773(5)$ & 0.003 (fix) & & & $9(1)$ & 113 & & $2.5-12$ & $1-4$ & $1,2,3$ & 0.85 \\
\hline & 015 & $2.8(4)$ & $2.22(1)$ & 0.003 (fix) & & & & & & & & & \\
\hline & 014 & 2 & $2.36(1)$ & 0.003 (fix) & & & & & & & & & \\
\hline & $\mathrm{OH} 2 \mathrm{O}$ & 2 & $2.41(2)$ & 0.003 (fix) & & & & & & & & & \\
\hline & C & 2 & $2.91(4)$ & 0.003 (fix) & & & & & & & & & \\
\hline & U-Oax2-U-Oax2 (MS) & & $3.545(7)$ & 0.006 (fix) & & & & & & & & & \\
\hline \multirow[t]{7}{*}{ Reduced-CD1577 } & Oax2 & $2^{* *}$ & $1.74(2)$ & 0.003 (fix) & $0.47(10)$ & 0.94 & $8(3)$ & 199 & & $3-10.5$ & $1-4$ & $1,2,3$ & 0.85 \\
\hline & 015 & $2^{* *}$ & $2.35(7)$ & 0.003 (fix) & $0.47(10)$ & 0.94 & & & & & & & \\
\hline & 014 & $2^{* *}$ & 2.33 (fix) & 0.003 (fix) & $0.47(10)$ & 0.94 & & & & & & & \\
\hline & $\mathrm{OH} 20$ & $2^{* *}$ & 2.37 (fix) & & & 0.94 & & & & & & & \\
\hline & $\mathrm{O} 1$ (coffinite) & $2^{* *}$ & $2.25(3)$ & 0.003 (fix) & $0.53(10)$ & 1.06 & & & & & & & \\
\hline & $\mathrm{O} 2$ (coffinite) & $4^{* *}$ & $2.83(3)$ & 0.003 (fix) & $0.53(10)$ & 2.12 & & & & & & & \\
\hline & U1 (coffinite) & $4^{* *}$ & $3.79(4)$ & $0.005(4)$ & $0.53(10)$ & 2.12 & & & & & & & \\
\hline
\end{tabular}

$400 *$ These distances were constrained to be the same as those of MR5766c and were fitted together.

$401 * *$ The number of ligands was fixed, the fraction of each mineral component was refined. 



403

404 Figure 6 EXAFS data and fits, shown in (A) k-space; (B) R-space; (C) R- Imaginary. The uranyl405 like spectra are shown at the top of each graph for MR5766c, MR5613a and CD1577

406 oxidised spectra (ox-MR) with relevant paths shown below. The reduced spectra (red-MR)

407 from CD1577 is shown below in Red and relevant paths underneath.

408

\subsubsection{Fitting of the reduced-CD1577 EXAFS spectra}

410 The spectrum of the reduced component from the lignite (reduced-MR, CD 1577) was fitted

411 using a wide variety of models. We report here a simple model (SI Table 3) based on a combination of paths corresponding to uranopilite $\left[\left(\mathrm{UO}_{2}\right)_{6}\left(\mathrm{SO}_{4}\right) \mathrm{O}_{2}(\mathrm{OH})_{6}\left(\mathrm{H}_{2} \mathrm{O}\right) 6 \cdot 8 \mathrm{H}_{2} \mathrm{O}\right]$, as a proxy for the uranyl component (amcsd 0005730; (Burns, 2001); and coffinite [USiO 4 ] (icsd 15484; (Fuchs and Gebert, 1958), which is the main U mineral according to micro-XRD (SI Figure 1). The best fit was obtained using $47(10) \%$ uranopilite and 53(9.8) \% coffinite. The presence of atoms at $\sim 3.8 \AA$ distance indicates a second shell of $U$ consistent with the crystal 417 structure of coffinite (EXAFS fit U-U distance of 3.79(4); crystallographic distance of $4183.83(2) \AA ̊$ ). Furthermore, Bhattacharyya et al. (2017) report a U-C distance of $2.90 \AA$ for their 
organic U(IV) structure, but this contribution is absent from the reduced-MR sample. Thus,

420 in contrast to $\mathrm{U}(\mathrm{VI})$, which is present in mostly monomeric form within the organic matrix,

$421 \mathrm{U}(\mathrm{IV})$ is present in mineral form (predominantly coffinite in CD 1577).

\section{Discussion}

\section{$423 \quad 5.1 \quad \mathrm{U}-\mathbf{O M}$ association at MR}

424 Accumulation of $U$ by $\mathrm{OM}$ by $10^{\prime}$ s of 1000 's of times relative to $U$-concentrations in 425 groundwater is a common and long established feature. Analyses of groundwater by 426 Douglas et al. (2011) show that modern waters at MR contain ppb concentrations of $U$

$427\left(8 \mu \mathrm{g} \mathrm{L}^{-1}\right)$, hence implying concentrations of up to $>6$ orders of magnitude in the OM layers 428 (mean $=2500 \mathrm{mg} \mathrm{kg}^{-1} \mathrm{U}, \max =15,000 \mathrm{mg} \mathrm{kg}^{-1} \mathrm{U}$ ). The highest concentrations of $\mathrm{U}$ at $\mathrm{MR}$ were associated with high concentrations of organic carbon, with $84 \%$ of the total $U$ in half 430 the sample set $(n=9)$ containing $>22-60$ wt. \% TOC. According to Douglas et al. (2011), 431 uranium and the associated metals precipitated syngenetically with OM as it was deposited 432 during a humid phase in the Late Eocene. Subsequent small-scale mobilisation during diagenesis and/or weathering concentrated the metals in the upper $2 \mathrm{~m}$ of the lignite, with

434 the latest episode in the last 300,000 years. Continuous upgrading via interaction with 435 groundwater containing low concentrations of dissolved $U$ could also have contributed to the high grades observed today.

437 A characteristic of the OM-rich layers is that the proportion of $\mathrm{U}(\mathrm{VI})$ is relatively consistent (e.g. $77.2 \% \pm 18$ from extractions), despite the fact that absolute $U$ concentrations vary greatly. Correlation coefficients between $\mathrm{U}$ and $\mathrm{OM}$ in soils and sediments in the literature are highly variable (Meunier et al., 1989; Landais, 1996; Min et al., 2000; Regenspurg et al., 
442 OM-rich samples contained most of the $U$ identified across all the studied samples, yet no 443 statistically significant correlation existed between grade and OM content. We infer that $U$ 444 introduced in oxidized form (uranyl complexes) by groundwater flowing through the OM445 rich sediments sorbed strongly and immediately to the available sites on the organic carbon.

446 We examined MR samples for $U$ oxidation state, as this parameter controls the potential for $447 \mathrm{U}$ mobility and biotoxicity, as well as providing necessary data to inform design of the ore448 forming process. The results of both $\mathrm{XAS}$ and $\mathrm{HCO}_{3}{ }^{-}$-chemical extractions show that on 449 average $71 \%$ of the total $\mathrm{U}$ (mean of $69 \% \mathrm{HCO}_{3}$ extraction and $74 \%$ XAS LCF) was in the $\mathrm{U}(\mathrm{VI})$ 450 oxidation state in the MR samples. That most of the $U$ was observed as $U(V I)$ was surprising 451 given the long-held assumption that for long-term $U$ immobilisation and accumulation to 452 occur within OM-rich sediments, reduction would be more important than adsorption 453 (Spirakis, 1996). In the case of MR specifically, the presence of high proportions of reduced $454 \mathrm{U}$ might also have been expected, given the low to neutral $\mathrm{pH}$ (3.5 to 7), reducing 455 conditions, and abundant coffinite/uraninite particles within the ores (Douglas et al., 2011). 456 However, while $\mathrm{U}$ phase stability modelling at low $\mathrm{pH}$ and Eh predicts that uraninite $\left(\mathrm{UO}_{2}\right)$ 457 and coffinite (under quartz-supersaturation conditions; Brugger et al., (2005)) are the 458 dominant phases in the absence of OM (Langmuir, 1978), models that include OM as 459 humate suggest a U(VI)-humate phase dominating at pH 6 (Shanbhag and Choppin, 1981; 460 Lenhart et al., 1997; Cumberland et al., 2016).

461 Recent studies have shown that modern OM-rich soils contain a high proportion of U(VI) (32 $462-65 \% \mathrm{U}(\mathrm{VI})$ in peats, and 51 to $100 \% \mathrm{U}(\mathrm{VI})$ in organic-rich alpine soils; (Regenspurg et al., 463 2010; Mikutta et al., 2016). Hence, the predominance of U(VI) at MR might be explained by 
that $U$ has been present at $M R$ long enough to cause radiolytic damage to organic biomarkers. We therefore interpret that since the first sediments were deposited, $U(V I)$ reduction has not played a major role in immobilizing $U$, despite the fact that $M R$ is a shallow $(<50 \mathrm{~m})$ deposit undergoing deep weathering, and has remained in contact with groundwater containing $\mu \mathrm{g} \mathrm{\textrm {L } ^ { - 1 }}$ levels of $\mathrm{U}$. Furthermore, the ores exist in an environment where both inorganic and microbial redox processes are expected to be promoted - as indeed demonstrated locally by the abundance of biogenic sulphide minerals.

\subsection{Uranium - organic matter complexes}

473 The poor capability of pure water to extract $U$ compared to the bicarbonate leach $(2.5 \%$

474 versus $69 \%$ extraction) suggests poor $U(V I)$ solubility and strong $U(V I)$ association to particulate OM (i.e. > $1.2 \mu \mathrm{m}$ filter-size) or possibly finely dispersed silica. We therefore postulate that particulate $\mathrm{OM}$ has helped to retard $U$ mobility at MR, especially since only very low concentrations of $U$ persisted within neighbouring sandstone sediments that were lower in organic carbon.

Mikutta et al. (2016) reported that uranyl present in modern peats (e.g. $<13,000$ years) is surrounded by 0.9 to 2.0 carbons at $2.89-2.93 \AA$. Therefore the speciation in the MR lignite, where we identified a bidentate C coordination at similar distance (2.90(7) to $2.93(3) \AA$ ) appears to be surprisingly similar to that in modern peat. This U-carbon model is also consistent with that of Denecke et al. (1998a; 1998b), representing poorly-ordered $\mathrm{UO}_{2}{ }^{2+}$ bonding to $\mathrm{COOH}^{-}$(carboxylic acid) groups present in organic macromolecules (Kaplan et al., 2016). Such bonding is likely at MR, considering that Douglas et al. (2011) found that up to $13.1 \%$ of the carbon is present in carboxyl groups within the MR OM-rich sediments. 
Bhattacharyya et al. (2017) showed that uranium could remain attached to these carboxyl

488

489

490

491

492

493

494

495

496

497

498

499

500

501

502

503

504

505

506

507 Our results extend a growing body of evidence that $U$ speciation in OM-rich geological 508 ligands even if $U$ was reduced in situ to $U(I V)$; however at $M R, U$ reduction appears to be mainly associated with the formation of coffinite and/or uraninite particles.

\section{Conclusion}

Our findings show that uranium at Mulga Rock was mostly (85\%) associated with the organic-rich sediments, where most of it is present in the oxidised state of $\mathrm{U}(\mathrm{VI})(71 \%$ of total U). It is commonly assumed that the flow of groundwater largely determines the distribution of the $U$; however, this study found that $U$ was associated with higher organic matter concentrations, and therefore the mobility of $U$ can be inhibited by OM. Results from EXAFS analyses on the oxidised CD1577 spectra are consistent with the interpretation that uranium predominantly forms a bidendate $\mathrm{U}(\mathrm{VI})$ complex with two organic (likely carboxyl) groups.

Despite the dominant presence of $\mathrm{OM}, \mathrm{U}(\mathrm{VI})$ was found to be reduced only incompletely, even under low $\mathrm{pH}$ conditions. Hence, MR-OM itself did not readily reduce $U$, and reduction of $U$ was not required for immobilisation of uranium over geological time frames as applicable to Mulga Rock. Tetravalent $U$, which displayed consistency with a coffinite-like structure, was found to be widely present at Mulga Rock; these species most likely result from in situ $\mathrm{U}(\mathrm{VI})$ reduction as a consequence of heterogeneous secondary processes, such as biomediated sulfate reduction and pyrite mineralisation and/or microbial enzymatic activity.

materials involves a complex mixture of $U(I V)$ and $U(V I)$, representing potentially 
overprinting generations of $U$ delivery by groundwater and subsequent biologically-

510 mediated $\mathrm{U}(\mathrm{VI})$ reduction. These results have direct implications for the development of $\mathrm{U}$ -

511 OM chemical extraction methods and post-mining management practices: In the context of

512 in-situ recovery, oxidation is not necessarily required for mobilising $U$, as $U(V I)$ is present in

513 higher proportions than previously assumed. In the case of remediation, environmental

514 management strategies can shift from a focus on $U$ reduction to using OM to capture $U$ in its

515 uranyl form, as a potentially equally effective or preliminary approach to $U$ remediation.

516 Future research into different forms of environmental U-OM interactions, in the presence of

517 other potentially reactive components such as mineral surfaces and microorganisms, is

518 necessary, to understand the conditions under which $U$ can be released or immobilised in

519 OM-rich waters and sediments.

\section{Acknowledgements}

521 This work was funded through a grant to JWM from the CSIRO Organic Geochemistry of 522 Mineral Systems (OGMS) Research Cluster. Parts of this research were undertaken on the

523 XAS and XFM beamline at the Australian Synchrotron, part of ANSTO. We would like to 524 thank: Xavier Moreau (Vimy Resources) for MR samples; Dr Alan Grieg, Graham Hutchinson 525 and Dr Hong Vu for laboratory assistance; Prof. Lorenz Schwark (University of Kiel) for TOC, $526 \mathrm{~N}$ and S data analysis; Dr Martin De Jonge and Dr Daryl Howard for beamline assistance at 527 AS XFM, Museum Victoria for comparative minerals, and Steven Henderson for his editorial contributions. SC would like to thank the Australian Synchrotron (AS) for beamtime and the

529 AS and Monash University for support in preparation of this manuscript through a joint 530 post-doctoral fellowship. 
534 Alessi, D.S., Uster, B., Veeramani, H., Suvorova, E.I., Lezama-Pacheco, J.S., Stubbs, J.E., Bargar, J.R., Bernier-Latmani, R., 2012. Quantitative Separation of Monomeric U(IV) from UO2 in Products of U(VI) Reduction. Environmental Science \& Technology 46, 6150-6157, doi:10.1021/es204123z.

Bargar, J.R., Williams, K.H., Campbell, K.M., Long, P.E., Stubbs, J.E., Suvorova, E.I., Lezama-Pacheco, J.S., Alessi, D.S., Stylo, M., Webb, S.M., Davis, J.A., Giammar, D.E., Blue, L.Y., Bernier-Latmani, R., 2013. Uranium redox transition pathways in acetate-amended sediments. Proceedings of the National Academy of Sciences 110, 4506-4511, doi:10.1073/pnas.1219198110.

Bhattacharyya, A., Campbell, K.M., Kelly, S.D., Roebbert, Y., Weyer, S., Bernier-Latmani, R., Borch, T., 2017. Biogenic non-crystalline U(IV) revealed as major component in uranium ore deposits. Nature Communications 8, 15538, doi:10.1038/ncomms15538.

Bone, S.E., Dynes, J.J., Cliff, J., Bargar, J.R., 2017. Uranium(IV) adsorption by natural organic matter in anoxic sediments. Proceedings of the National Academy of Sciences 114, 711-716, doi:10.1073/pnas.1611918114.

Bonnetti, C., Cuney, M., Michels, R., Truche, L., Malartre, F., Liu, X., Yang, J., 2015. The Multiple Roles of Sulfate-Reducing Bacteria and Fe-Ti Oxides in the Genesis of the Bayinwula Roll Front-Type Uranium Deposit, Erlian Basin, NE China. Economic Geology 110, 1059-1081.

Bonnetti, C., Liu, X., Zhaobin, Y., Cuney, M., Michels, R., Malartre, F., Mercadier, J., Cai, J., 2017. Coupled uranium mineralisation and bacterial sulphate reduction for the genesis of the Baxingtu sandstone-hosted U deposit, SW Songliao Basin, NE China. Ore Geology Reviews 82, 108-129, doi:10.1016/j.oregeorev.2016.11.013.

Brugger, J., Long, N., McPhail, D.C., Plimer, I., 2005. An active amagmatic hydrothermal system: The Paralana hot springs, Northern Flinders Ranges, South Australia. Chemical Geology 222, 35-64, doi:10.1016/j.chemgeo.2005.06.007.

Bryan, N.D., Abrahamsen, L., Evans, N., Warwick, P., Buckau, G., Weng, L., Van Riemsdijk, W.H., 2012. The effects of humic substances on the transport of radionuclides: Recent improvements in the prediction of behaviour and the understanding of mechanisms. Applied Geochemistry 27, 378389, doi:10.1016/j.apgeochem.2011.09.008.

Burns, P.C., 2001. A new uranyl sulfate chain in the structure of uranopilite. The Canadian Mineralogist 39, 1139-1146.

Campbell, K.M., Gallegos, T.J., Landa, E.R., 2015. Biogeochemical aspects of uranium mineralization, mining, milling, and remediation. Applied Geochemistry 57, 206-235, doi:10.1016/j.apgeochem.2014.07.022.

Cumberland, S.A., Douglas, G., Grice, K., Moreau, J.W., 2016. Uranium mobility in organic matter-rich sediments: A review of geological and geochemical processes. Earth-Science Reviews 159, 160-185, doi:10.1016/j.earscirev.2016.05.010.

de Lill, D.T., Chan, B.C., 2013. Structure and luminescence of a one-dimensional uranium coordination polymer assembled through benzophenone-4,4'-dicarboxylate. Inorganica Chimica Acta 404, 215-218, doi:https://doi.org/10.1016/j.ica.2013.03.006.

Dean, W.E., 1974. Determination of carbonate and organic matter in calcareous sedimentry rocks by loss of ignition:Comparison with other methods. Journal of Sedimentary Petrology 44, 242-248, doi:doi:10.1306/74D729D2-2B21-11D7-8648000102C1865D

Deditius, A.P., Utsunomiya, S., Ewing, R.C., 2008. The chemical stability of coffinite, USiO4.nH(2)O; $0<\mathrm{n}<2$, associated with organic matter: A case study from Grants uranium region, New Mexico, USA. Chemical Geology 251, 33-49, doi:10.1016/j.chemgeo.2008.02.009.

Denecke, M.A., Reich, T., Bubner, M., Pompe, S., Heise, K.H., Nitsche, H., Allen, P.G., Bucher, J.J., Edelstein, N.M., Shuh, D.K., 1998a. Determination of structural parameters of uranyl ions complexed 
with organic acids using EXAFS. Journal of Alloys and Compounds 271, 123-127, doi:10.1016/s09258388(98)00038-3.

Denecke, M.A., Reich, T., Pompe, S., Bubner, M., Heise, K.H., Nitsche, H., Allen, P.G., Bucher, J.J., Edelstein, N.M., Shuh, D.K., Czerwinski, K.R., 1998b. EXAFS investigations of the interaction of humic acids and model compounds with uranyl cations in solid complexes. Radiochimica Acta 82, 103-108. Douglas, G.B., Butt, C.R.M., Gray, D.J., 2011. Geology, geochemistry and mineralogy of the lignitehosted Ambassador palaeochannel uranium and multi-element deposit, Gunbarrel Basin, Western Australia. Mineralium Deposita 46, 761-787, doi:10.1007/s00126-011-0349-4.

Douglas, G.B., Gray, D.J., Butt, C.M., 1993. Geochemistry, minerology and hydrogeochemistry of the Ambassador multi-element lignite deposit, Western Australia: With additional investigations on the characterization of organic matter. CSIRO, Australia.

Eggins, S.M., Woodhead, J.D., Kinsley, L.P.J., Mortimer, G.E., Sylvester, P., McCulloch, M.T., Hergt, J.M., Handler, M.R., 1997. A simple method for the precise determination of $\geq 40$ trace elements in geological samples by ICPMS using enriched isotope internal standardisation. Chemical Geology 134, 311-326, doi:https://doi.org/10.1016/S0009-2541(96)00100-3.

Etschmann, B.E., Ryan, C.G., Brugger, J., Kirkham, R., Hough, R.M., Moorhead, G., Siddons, D.P., De Geronimo, G., Kuczewski, A., Dunn, P., Paterson, D., de Jonge, M.D., Howard, D.L., Davey, P., Jensen, M., 2010. Reduced As components in highly oxidized environments: Evidence from full spectral XANES imaging using the Maia massively parallel detector. American Mineralogist 95, 884-887, doi:10.2138/am.2010.3469.

Fuchs, L.H., Gebert, E., 1958. X-Ray Studies of Synthetic Coffinite, Thorite and Uranothorites. American Mineralogist 43, 243-248.

Greenwood, P., Brocks, J., Grice, K., Schwark, L., Jaraula, C., Dick, J., Evans, K., 2013. Organic Geochemistry and Mineralogy: I. Characterisation of Organic Matter Associated with Metal Deposits. Ore Geology Reviews, 1-27, doi:10.1016/j.oregeorev.2012.10.004.

605 Grenthe, I., Fuger, J., Konings, R.J.M., Lemire, R.J., Muller, A.B., Nguyen-Trung, C., Wanner, H., 2004. Chemical Thermodynamics of Uranium. OECD- NEA, Paris, France.

607 Guillaumont, R., Fanghanel, T., Neck, V., Fuger, J., Palmer, D., Grenthe, I., Rand, M.H., 2003. Update on the chemical thermodynamics of uranium, neptunium, plutonium, americium, and technetium. OECD, Nuclear Energy Agency, Paris, France, p. 959. Heiri, O., Lotter, A., Lemcke, G., 2001. Loss on ignition as a method for estimating organic and carbonate content in sediments: reproducibility and comparability of results. Journal of Paleolimnology 25, 101-110, doi:10.1023/a:1008119611481. Idiz, E.F., Carlisle, D., Kaplan, I.R., 1986. Interaction between organic matter and trace metals in a uranium rich bog, Kern County, California, U.S.A. Applied Geochemistry 1, 573-590, doi:10.1016/0883-2927(86)90065-X.

Jaraula, C.M.B., Schwark, L., Moreau, X., Pickel, W., Bagas, L., Grice, K., 2015. Radiolytic alteration of biopolymers in the Mulga Rock uranium deposit. Applied Geochemistry 52, 97-108, doi:10.1016/j.apgeochem.2014.11.012.

Kamber, B.S., Greig, A., Schoenberg, R., Collerson, K.D., 2003. A refined solution to Earth's hidden niobium: implications for evolution of continental crust and mode of core formation. Precambrian Research 126, 289-308, doi:https://doi.org/10.1016/S0301-9268(03)00100-1.

Kanematsu, M., Perdrial, N., Um, W., Chorover, J., O’Day, P.A., 2014. Influence of Phosphate and Silica on $\mathrm{U}(\mathrm{VI})$ Precipitation from Acidic and Neutralized Wastewaters. Environmental Science \& Technology 48, 6097-6106, doi:10.1021/es4056559.

Kaplan, D.I., Xu, C., Huang, S., Lin, Y., Tolić, N., Roscioli-Johnson, K.M., Santschi, P.H., Jaffé, P.R., 2016. Unique Organic Matter and Microbial Properties in the Rhizosphere of a Wetland Soil. Environmental Science \& Technology 50, 4169-4177, doi:10.1021/acs.est.5b05165.

629 11, 33-51, doi:10.1016/0169-1368(95)00014-3. 
Langmuir, D., 1978. Uranium solution-mineral equilibria at low temperatures with applications to sedimentary ore deposits. Geochimica et Cosmochimica Acta 42, 547-569, doi:10.1016/00167037(78)90001-7. Latta, D.E., Mishra, B., Cook, R.E., Kemner, K.M., Boyanov, M.I., 2014. Stable U(IV) Complexes Form doi:10.1021/es4047389.

Law, G.T.W., Geissler, A., Burke, I.T., Livens, F.R., Lloyd, J.R., McBeth, J.M., Morris, K., 2011. Uranium Redox Cycling in Sediment and Biomineral Systems. Geomicrobiology Journal 28, 497-506, doi:10.1080/01490451.2010.512033.

Lenhart, J.J., Figueroa, L.A., Honeyman, B.D., Kaneko, D., 1997. Modeling the adsorption of U(VI) onto animal chitin using coupled mass transfer and surface complexation. Colloids and Surfaces $A$ : Physicochemical and Engineering Aspects 120, 243-254, doi:10.1016/S0927-7757(96)03865-4.

Li, K., Etschmann, B., Rae, N., Reith, F., Ryan, C.G., Kirkham, R., Howard, D., Rosa, D.R.N., Zammit, C., Pring, A., Ngothai, Y., Hooker, A., Brugger, J., 2016. Ore Petrography Using Megapixel X-Ray Imaging: Rapid Insights into Element Distribution and Mobilization in Complex Pt and U-Ge-Cu Ores. Economic Geology 111, 487-501, doi:10.2113/econgeo.111.2.487.

Lidman, F., Mörth, C.M., Laudon, H., 2012. Landscape control of uranium and thorium in boreal streams - spatiotemporal variability and the role of wetlands. Biogeosciences 9, 4773-4785, doi:10.5194/bg-9-4773-2012.

Luo, W., Gu, B., 2008. Dissolution and Mobilization of Uranium in a Reduced Sediment by Natural Humic Substances under Anaerobic Conditions. Environmental Science \& Technology 43, 152-156, doi:10.1021/es8013979.

Mehta, V.S., Maillot, F., Wang, Z., Catalano, J.G., Giammar, D.E., 2014. Effect of co-solutes on the products and solubility of uranium(VI) precipitated with phosphate. Chemical Geology 364, 66-75, doi:10.1016/j.chemgeo.2013.12.002.

Meunier, J.D., Trouiller, A., Brulhert, J., Pagel, M., 1989. Uranium and organic matter in a paleodeltaic environment; the Coutras Deposit (Gironde, France). Economic Geology 84, 1541-1556.

Mikutta, C., Langner, P., Bargar, J.R., Kretzschmar, R., 2016. Tetra- and Hexavalent Uranium Forms Bidentate-Mononuclear Complexes with Particulate Organic Matter in a Naturally Uranium-Enriched Peatland. Environmental Science \& Technology 50, 10465-10475, doi:10.1021/acs.est.6b03688.

Min, M.Z., Meng, Z.W., Sheng, G.Y., Min, Y.S., Liu, X., 2000. Organic geochemistry of paleokarsthosted uranium deposits, South China. Journal of Geochemical Exploration 68, 211-229, doi:10.1016/s0375-6742(99)00085-0.

Newsome, L., Morris, K., Lloyd, J.R., 2014. The biogeochemistry and bioremediation of uranium and other priority radionuclides. Chemical Geology 363, 164-184, doi:10.1016/j.chemgeo.2013.10.034.

Och, L.M., Müller, B., März, C., Wichser, A., Vologina, E.G., Sturm, M., 2016. Elevated uranium concentrations in Lake Baikal sediments: Burial and early diagenesis. Chemical Geology 441, 92-105, doi:10.1016/j.chemgeo.2016.08.001.

Owen, D.E., Otton, J.K., 1995. Mountain wetlands: Efficient uranium filters - potential impacts. Ecological Engineering 5, 77-93, doi:10.1016/0925-8574(95)00013-9.

Paterson, D., de Jonge, M.D., Howard, D.L., Lewis, W., McKinlay, J., Starritt, A., Kusel, M., Ryan, C.G., Kirkham, R., Moorhead, G., Siddons, D.P., 2011. The X-ray Fluorescence Microscopy Beamline at the Australian Synchrotron. In: McNulty, I., Eyberger, C., Lai, B. (Eds.). 10th International Conference on X-Ray Microscopy, pp. 219-222.

Ravel, B., Newville, M., 2005. ATHENA, ARTEMIS, HEPHAESTUS: data analysis for X-ray absorption spectroscopy using IFEFFIT. Journal of Synchrotron Radiation 12, 537-541, doi:10.1107/s0909049505012719.

Read, D., Bennett, D.G., Hooker, P.J., Ivanovich, M., Longworth, G., Milodowski, A.E., Noy, D.J., 1993. The migration of uranium into peat-rich soils at Broubster, Caithness, Scotland, U.K. Journal Of Contaminant Hydrology 13, 291-308, doi:10.1016/0169-7722(93)90067-3. 
680 Regenspurg, S., Margot-Roquier, C., Harfouche, M., Froidevaux, P., Steinmann, P., Junier, P., Bernier681 Latmani, R., 2010. Speciation of naturally-accumulated uranium in an organic-rich soil of an alpine 682 region (Switzerland). Geochimica et Cosmochimica Acta 74, 2082-2098, 683 doi:10.1016/j.gca.2010.01.007.

684 Rehr, J.J., Kas, J.J., Vila, F.D., Prange, M.P., Jorissen, K., 2010. Parameter-free calculations of X-ray spectra with FEFF9. Physical Chemistry Chemical Physics 12, 5503-5513, doi:10.1039/b926434e. Renock, D., Mueller, M., Yuan, K., Ewing, R.C., Becker, U., 2013. The energetics and kinetics of uranyl reduction on pyrite, hematite, and magnetite surfaces: A powder microelectrode study. Geochimica et Cosmochimica Acta 118, 56-71, doi:10.1016/j.gca.2013.04.019.

Rowell, D.L., 1994. Soil Science Methods and Applications. Longman UK, Harlow, England.

Ryan, C., 2000. Quantitative trace element imaging using PIXE and the nuclear microprobe. International Journal of Imaging Systems and Technology 11, 219-230.

Ryan, C., Jamieson, D., 1993. Dynamic analysis: on-line quantitative PIXE microanalysis and its use in overlap-resolved elemental mapping. Nuclear Instruments and Methods in Physics Research Section B: Beam Interactions with Materials and Atoms 77, 203-214.

Ryan, C.G., Siddons, D.P., Kirkham, R., Li, Z.Y., Jonge, M.D.d., Paterson, D.J., Kuczewski, A., Howard, D.L., Dunn, P.A., Falkenberg, G., Boesenberg, U., Geronimo, G.D., Fisher, L.A., Halfpenny, A., Lintern, M.J., Lombi, E., Dyl, K.A., Jensen, M., Moorhead, G.F., Cleverley, J.S., Hough, R.M., Godel, B., Barnes, S.J., James, S.A., Spiers, K.M., Alfeld, M., Wellenreuther, G., Vukmanovic, Z., Borg, S., 2014. Maia Xray fluorescence imaging: Capturing detail in complex natural samples. Journal of Physics: Conference Series 499, 012002.

Shanbhag, P.M., Choppin, G.R., 1981. Binding of uranyl by humic acid. Journal of Inorganic and Nuclear Chemistry 43, 3369-3372, doi:10.1016/0022-1902(81)80117-0.

Spirakis, C.S., 1996. The roles of organic matter in the formation of uranium deposits in sedimentary rocks. Ore Geology Reviews 11, 53-69, doi:10.1016/0169-1368(95)00015-1.

Tinnacher, R.M., Nico, P.S., Davis, J.A., Honeyman, B.D., 2013. Effects of Fulvic Acid on Uranium(VI) Sorption Kinetics. Environmental Science \& Technology 47, 6214-6222, doi:10.1021/es304677c.

Tokunaga, T.K., Kim, Y., Wan, J., Yang, L., 2012. Aqueous Uranium(VI) Concentrations Controlled by Calcium Uranyl Vanadate Precipitates. Environmental Science \& Technology 46, 7471-7477, doi:10.1021/es300925u.

Tokunaga, T.K., Wan, J.M., Pena, J., Brodie, E.L., Firestone, M.K., Hazen, T.C., Sutton, S.R., Lanzirotti, A., Newville, M., 2005. Uranium reduction in sediments under diffusion-limited transport of organic carbon. Environmental Science \& Technology 39, 7077-7083, doi:10.1021/es050221a.

Tsarev, S., Collins, R.N., Fahy, A., Waite, T.D., 2016. Reduced Uranium Phases Produced from Anaerobic Reaction with Nanoscale Zerovalent Iron. Environmental Science \& Technology 50, 25952601, doi:10.1021/acs.est.5b06160.

Vimy, 2014. Mulga Rock Uranium Project Resource Upgrade. Perth.

Vimy, 2015. Pre-Feasibility Study Reaffirms Mulga Rock Project as one of Australia's Leading Undeveloped Uranium Projects

Vimy, 2016a. Resource Update for Mulga Rock Project.

Vimy, 2016b. Significant Resource Upgrade for Mulga Rock Project.

Vimy, 2016c. Vimy Resources Limited; Annual Report 2016. Perth, p. 98.

Warwick, P., Evans, N., Hall, A., Walker, G., Steigleder, E., 2005. Stability constants of U(VI) and U(IV)humic acid complexes. Journal of Radioanalytical and Nuclear Chemistry 266, 179-190, doi:10.1007/s10967-005-0890-7.

Wood, S.A., 1996. The role of humic substances in the transport and fixation of metals of economic interest (Au, Pt, Pd, U, V). Ore Geology Reviews 11, 1-31, doi:10.1016/0169-1368(95)00013-5.

Wülser, P.-A., Brugger, J., Foden, J., Pfeifer, H.-R., 2011. The Sandstone-Hosted Beverley Uranium Deposit, Lake Frome Basin, South Australia: Mineralogy, Geochemistry, and a Time-Constrained Model for Its Genesis. Economic Geology 106, 835-867, doi:10.2113/econgeo.106.5.835. 
730 Zammit, C.M., Brugger, J., Southam, G., Reith, F., 2014. In situ recovery of uranium - the microbial 731 influence. Hydrometallurgy 150, 236-244, doi:10.1016/j.hydromet.2014.06.003.

732 Zhao, D., Wang, X., Yang, S., Guo, Z., Sheng, G., 2012. Impact of water quality parameters on the 733 sorption of $\mathrm{U}(\mathrm{VI})$ onto hematite. Journal of Environmental Radioactivity 103, 20-29, 734 doi:10.1016/j.jenvrad.2011.08.010.

735 Zhou, P., Gu, B.H., 2005. Extraction of oxidized and reduced forms of uranium from contaminated 736 soils: Effects of carbonate concentration and pH. Environmental Science \& Technology 39, 44354440, doi:10.1021/es0483443. 


\section{Characterization of uranium redox state in organic-rich}

\section{Eocene sediments}

3 Susan A Cumberland ${ }^{1,2,3}$, Barbara Etschmann ${ }^{2}$, Joël Brugger ${ }^{2}$, Grant Douglas ${ }^{4}$, Katy Evans ${ }^{5}$,

$4 \quad$ Louise Fisher ${ }^{6}$, Peter Kappen ${ }^{3}$, John W. Moreau ${ }^{1}$

51 School of Earth Sciences, University of Melbourne, Parkville, Victoria 3100, Australia

62 School of Earth, Atmosphere and Environment, Monash University, Clayton 3800, Victoria,

7 Australia

83 ANSTO Australian Synchrotron, 800 Blackburn Road, Clayton 3168, Victoria, Australia

94 CSIRO Land and Water, Floreat, Western Australia, Australia

105 Western Australian School of Mines, Curtin University, Bentley, Western Australia, Australia

116 CSIRO Mineral Resources, Bentley, Western Australia, Australia

12

13 
Supplementary Information

\section{SUPPLEMENTARY INFORMATION}

15 SI Table 1 Location and drill depth of cores analysed

\begin{tabular}{llrrrrrr}
\hline Hole Id & Deposit & Samples from core & Northing & Easting & RL & Core Depth & Type \\
& & & & & & & \\
& & & & & & & \\
\hline NNA 5612 & Princess & MR5612a,b & 6684044.69 & 578834.44 & 342.8 & 54 & AC \\
NNA 5613 & Princess & MR5613a,b & 6684001.28 & 578902.04 & 341.48 & 54 & AC \\
NNA 5636 & Princess & MR5636 & 6684253.49 & 579486.8 & 345.52 & 72 & AC \\
NNA 5706 & Emperor & MR5706a,b & 6690894.00 & 552782.00 & 334.5 & 62 & AC \\
NNA 5728 & Shogun & MR5728a,b & 6686912.00 & 563587.00 & 318.4 & 51.0 & AC \\
NNA 5766 & Ambassador & MR5766a,b,c,d & 6682660.00 & 576969.00 & 342.1 & 64 & AC \\
NND 5076 & Emperor & MR5076a,b & 6682834.90 & 579131.20 & 339.5 & 48.5 & DDH \\
NND 5077 & Ambassador & MR5077 & 6682189.32 & 576147.80 & 333 & 54.3 & DDH \\
NND 5078 & Ambassador & MR5078 & 6682605.99 & 577075.96 & 342.4 & 57.0 & DDH \\
CD1577 & Ambassador & & 6682708.94 & 579942.81 & 331.4 & 43.5 & DDH
\end{tabular}

$16 \mathrm{AC}=$ air core; $\mathrm{DDH}=$ diamond drill hole, $\mathrm{RL}=$ Reduced Level - elevation above sea level in metres of 17 the drill hole collar (Vimy, 2014, 2016b)

18

19 
Supplementary Information

SI Table 2 Uranium mineral standards and location where known

\begin{tabular}{|c|c|c|c|}
\hline Number & Name & Formula & Location \\
\hline M 33701 & andersonite & $\mathrm{Na}_{2} \mathrm{CaUO}_{2}\left(\mathrm{CO}_{3}\right)_{3} \cdot 6 \mathrm{H}_{2} \mathrm{O}$ & \\
\hline M 21676 & autunite & $\mathrm{Ca}\left(\mathrm{UO}_{2}\right)_{2}\left(\mathrm{PO}_{4}\right)_{2}$ & \\
\hline M 30851 & boltwoodite & $(\mathrm{Na}, \mathrm{K})\left(\mathrm{UO}_{2}\right)_{2}\left(\mathrm{HSiO}_{4}\right) \cdot \mathrm{H}_{2} \mathrm{O}$ & \\
\hline M 33175 & brannerite & $\mathrm{U} \mathrm{\textrm {TiO } _ { 4 }}$ & \\
\hline M 32495 & coffinite & $\mathrm{USiO}_{4}$ & \\
\hline M 28752 & coffinite & $\mathrm{USiO}_{4}$ & $\begin{array}{c}\text { USA, New Mexico Gransted, McKinley Country, Paddy } \\
\text { Murphy Mines (35 8 50N, } 107513 \text { W) }\end{array}$ \\
\hline M 33214 & curienite & $\mathrm{Pb}_{2}\left(\mathrm{UO}_{2}\right)_{2}\left(\mathrm{~V}_{2} \mathrm{O}_{8}\right)_{2} \cdot 5 \mathrm{H}_{2} \mathrm{O}$ & \\
\hline M 22869 & davidite & $(\mathrm{La}, \mathrm{Ce})(\mathrm{Y}, \mathrm{U}, \mathrm{Fe})(\mathrm{Ti}, \mathrm{Fe} 3+)_{20}(\mathrm{O}, \mathrm{HO})_{38}$ & \\
\hline M 45514 & saleeite & $\mathrm{Mg}\left(\mathrm{UO}_{2}\right)_{2}\left(\mathrm{PO}_{4}\right)_{2} \cdot 10 \mathrm{H}_{2} \mathrm{O}$ & \\
\hline M 44367 & schoepite & $\left(\mathrm{UO}_{2}\right) \mathrm{O}_{2}(\mathrm{OH})_{12} \cdot 12 \mathrm{H}_{2} \mathrm{O}$ & $\begin{array}{l}\text { Democratic Republic of Congo (Zaire), Shaba (Katanga) } \\
\text { Province, Kolwezi Munsonoi Mine (10 45 S } 2525 \text { E) }\end{array}$ \\
\hline M 17631 & torbernite & $\mathrm{Cu}\left(\mathrm{UO}_{2}\right)_{2}\left(\mathrm{PO}_{4}\right)_{2} \cdot 8-12 \mathrm{H}_{2} \mathrm{O}$ & \\
\hline M 27299 & soddyite & $\left(\mathrm{UO}_{2}\right) \mathrm{SiO}_{4}\left(\mathrm{H}_{2} \mathrm{O}\right)_{2}$ & $\begin{array}{c}\text { Democratic Republic of Congo (Zaire), Shaba (Katanga) } \\
\text { Province, Swamba }\end{array}$ \\
\hline M 26415 & uraninite & $\mathrm{UO}_{2}$ & \\
\hline M 19266 & uraninite & $\mathrm{UO}_{2}$ & Australia, Northern Territory, South Alligator River \\
\hline M 34470 & uranophane & $\mathrm{Ca}\left(\mathrm{UO}_{2}\right)_{2}\left(\mathrm{SiO}_{3}\right)(\mathrm{OH})_{2} \cdot 5 \mathrm{H}_{2} \mathrm{O}$ & \\
\hline M 40774 & uranopilite & $\left(\mathrm{UO}_{2}\right)_{6}\left(\mathrm{SO}_{4}\right) \mathrm{O}_{2}(\mathrm{OH})_{6}\left(\mathrm{H}_{2} \mathrm{O}\right)_{6}$ & \\
\hline M 34904 & uranopilite & $\left(\mathrm{UO}_{2}\right)_{6}\left(\mathrm{SO}_{4}\right) \mathrm{O}_{2}(\mathrm{OH})_{6}\left(\mathrm{H}_{2} \mathrm{O}\right)_{6}$ & $\begin{array}{l}\text { El Sherana mine, South Alligator River, NT, AU (13 } 31 \mathrm{~S} \\
\qquad 13231 \mathrm{E})\end{array}$ \\
\hline M 25802 & zippeite & $\mathrm{Mg}\left(\mathrm{UO}_{2}\right)_{6}\left(\mathrm{SO}_{4}\right)_{3}(\mathrm{OH})_{10}\left(\mathrm{H}_{2} \mathrm{O}\right)_{\mathrm{n}}$ & \\
\hline
\end{tabular}

21 Source: Museum Victoria, formulas are generic

22

23 
Supplementary Information

24 SI Table 3 EXAFS fitting and paths for the uranyl nitrate standard

\begin{tabular}{|c|c|c|c|c|c|c|c|c|c|}
\hline Ligand & $\mathbf{N}$ & $R(\AA ̊)$ & ss $\left(\AA^{2}\right)$ & $\Delta \mathrm{E}_{0}$ & $\operatorname{Red} X^{2}$ & k-range & R-range & k-weighting & $\mathrm{SO}^{2}$ \\
\hline 01 & 2 (fix) & $1.787(7)$ & $0.002(1)$ & $10(1)$ & 978 & $1-4.5 \AA^{-1}$ & $\begin{array}{l}2-12.5 \\
\AA\end{array}$ & $1,2,3$ & $\begin{array}{l}0.8 \\
5\end{array}$ \\
\hline $\mathrm{O} 2$ & 2 (fix) & $2.34(3)$ & $0.008(7)$ & & & & & & \\
\hline N1 & 2 (fix) & $2.47(4)$ & 0.003 (fix) & & & & & & \\
\hline $\mathrm{O} 3$ & 2 (fix) & $2.53(3)$ & 0.003 (fix) & & & & & & \\
\hline 04_2(path 37) & 4 (fix) & $4.30(3)$ & 0.003 (fix) & & & & & & \\
\hline \multirow[t]{4}{*}{ MS paths } & 21: 01-01 & $3.57(1)$ & $0.002(1)$ & & & & & & \\
\hline & 22: 01-01 & $3.57(1)$ & $0.002(1)$ & & & & & & \\
\hline & 24: N1-O1 & $3.65(4)$ & 0.0025 & & & & & & \\
\hline & 27: 03-01 & $3.71(3)$ & 0.0025 & & & & & & \\
\hline \multicolumn{10}{|c|}{ error (quadrature) for MS paths } \\
\hline \multicolumn{10}{|l|}{0.009899495} \\
\hline \multicolumn{10}{|l|}{0.040607881} \\
\hline 0.030805844 & & & & & & & & & \\
\hline
\end{tabular}

25 
Supplementary Information

26

27 SI Table 4 Summary of physicochemical data in MR cores $n=18$.

\begin{tabular}{|c|c|c|c|c|c|c|c|c|c|c|}
\hline Sample ID & Core & Depth (m) & Deposit & $\begin{array}{c}U \text { (mg kg- } \\
\text { 1) }\end{array}$ & $\mathrm{pH}$ & $\begin{array}{c}\text { TOC } \\
\%\end{array}$ & $\begin{array}{c}\mathrm{LOI}_{550} \\
\%\end{array}$ & $\begin{array}{c}\text { LOl }_{900} \\
\%\end{array}$ & $\begin{array}{c}\text { Carbonate } \\
\% \\
(* *) \\
\end{array}$ & $\begin{array}{c}\text { Total N } \\
\%\end{array}$ \\
\hline CD1577 & 1577 & 43.5 & $A m b$ & nd & nd & nd & nd & nd & nd & nd \\
\hline MR5076a & 5076 & $44.3-44.4$ & $A m b$ & 1877 & 5.24 & 39 & NA & NA & NA & 0.46 \\
\hline MR5076b & 5076 & $44.7-44.8$ & $A m b$ & 14930 & 3.09 & 30 & NA & NA & NA & 0.42 \\
\hline MR5077 & 5077 & $42.2-42.5$ & $A m b$ & 5760 & 4.12 & 44 & NA & NA & NA & 0.37 \\
\hline MR5078 & 5078 & 51.5-51.5 & $\mathrm{Amb}$ & 3720 & 3.02 & 34 & NA & NA & NA & 0.27 \\
\hline MR5612a & 5612 & $41-42$ & Pri & 2 & 4.7 & 60 & 57.7 & 78.3 & 17.3 & 0.35 \\
\hline MR5612b & 5612 & $43-44$ & Pri & 3.2 & 4.34 & 3.8 & NA & NA & NA & 0.04 \\
\hline MR5612c & 5612 & $45-46$ & Pri & 65 & 3.22 & 3.3 & NA & NA & NA & 0.05 \\
\hline MR5613a* & 5613 & $40-41$ & Pri & 5816 & 5.57 & 33.5 & 43.4 & 55.9 & 17.1 & 0.23 \\
\hline MR5613b* & 5613 & $41-43$ & Pri & 4588 & 5.61 & 39.5 & NA & NA & NA & 0.23 \\
\hline MR5636 & 5636 & $55-56$ & Pri & 278 & 4.96 & 3.2 & NA & NA & NA & 0.05 \\
\hline MR5706a & 5706 & $42-43$ & Emp & 115 & 3.15 & 22 & 19.1 & 30.6 & 15.7 & 0.33 \\
\hline MR5706b & 5706 & $55-56$ & Emp & 40 & 7.06 & 0.72 & 1 & 1 & 0.1 & 0.02 \\
\hline MR5728a & 5728 & $28.5-29$ & Sho & 5590 & 3.33 & 26 & 37.9 & 41.9 & 5.1 & 0.29 \\
\hline MR5728b & 5728 & $34-34.5$ & Sho & 113 & 3.64 & 3.6 & 3.3 & 3.5 & 0.2 & 0.03 \\
\hline MR5766a & 5766 & 53-53.5 & $A m b$ & 5012 & 4.35 & 15.1 & 19.4 & 28.9 & 13 & 0.18 \\
\hline MR5766b* & 5766 & $55.5-56$ & $A m b$ & 623 & 5.43 & 16 & 21.5 & 24.6 & 4.2 & 0.1 \\
\hline MR5766c* & 5766 & $56.5-57$ & Amb & 1206 & 4.60 & 21 & 22.5 & 33.2 & 14.6 & 0.14 \\
\hline MR5766d & 5766 & 58-58.5 & Amb & 621 & 4.72 & 13 & 10.5 & 12.6 & 2.9 & 0.09 \\
\hline Mean & & & & 2798 & 4.5 & 22.5 & 23.6 & 31.1 & 9 & 0.2 \\
\hline Min & & & & 1.9 & 3 & 0.7 & 1 & 1 & 0.1 & 0 \\
\hline Max & & & & 14932 & 7.1 & 58.8 & 57.7 & 78.3 & 17.3 & 0.5 \\
\hline$S D$ & & & & 3805 & 1.1 & 16.8 & 17.9 & 23.6 & 7.1 & 0.1 \\
\hline Median & & & & 914.2 & 4.5 & 21.2 & 20.4 & 29.8 & 9.1 & 0.2 \\
\hline
\end{tabular}

28 *EXAFS Data available

$29{ }^{* *} \mathrm{NB}$ estimated $\mathrm{CO}_{3}{ }^{2}$ was calculated by $\mathrm{LO}_{900}-\mathrm{LOI}_{550} \times \mathrm{MW} \mathrm{C/} 100$ (Dean, 1974; Heiri et al., 2001). Sample ID is the lab number 30 given by Melbourne University. NA = not analysed 
Supplementary Information

31 SI Table 5 Elemental data for cores (1/2)

32

\begin{tabular}{|c|c|c|c|c|c|c|c|c|c|c|c|c|}
\hline Sample number & Core & $\begin{array}{c}\text { Depth } \\
\text { m }\end{array}$ & Deposit & $\begin{array}{l}\mathrm{U}(\mathrm{XRF}) \\
\mathrm{mg} \mathrm{kg}^{-1}\end{array}$ & $\begin{array}{l}\mathrm{U} \text { ashed } \\
\mathrm{mg} \mathrm{kg}^{-1}\end{array}$ & $\begin{array}{c}\mathrm{U} \\
\mathrm{mg} \mathrm{kg}^{-1}\end{array}$ & $\begin{array}{c}\text { As } \\
\mathrm{mg} \mathrm{kg}^{-1}\end{array}$ & $\begin{array}{c}\mathrm{Be} \\
\mathrm{mg} \mathrm{kg}^{-1}\end{array}$ & $\begin{array}{c}\mathrm{Ca} \\
\mathrm{mg} \mathrm{kg}^{-1}\end{array}$ & $\begin{array}{c}\text { Co } \\
\mathrm{mg} \mathrm{kg}^{-1}\end{array}$ & $\begin{array}{c}\mathrm{Cr} \\
\mathrm{mg} \mathrm{kg}^{-1}\end{array}$ & $\begin{array}{c}\mathrm{Cu} \\
\mathrm{mg} \mathrm{kg}^{-1}\end{array}$ \\
\hline MR5076a & 5076 & $44.3-44.4$ & $A m b$ & NA & ND & 1880 & 17 & 16 & 12900 & 282 & 261 & 624 \\
\hline MR5076b & 5076 & $44.7-44.8$ & $\mathrm{Amb}$ & NA & ND & 14900 & 296 & 128 & 5290 & 4300 & 163 & 7290 \\
\hline MR5077 & 5077 & $42.2-42.5$ & $A m b$ & NA & ND & 5760 & 49 & 3 & 2950 & 142 & 880 & 458 \\
\hline MR5078 & 5078 & $51.5-51.5$ & $\mathrm{Amb}$ & NA & ND & 3720 & 157 & 19 & 34 & 541 & 337 & 1500 \\
\hline MR5766a & 5766 & 53-53.5 & Amb & 5280 & 5198.0 & 5010 & 50 & 20 & 2450 & 2960 & 535 & 696 \\
\hline MR5766b & 5766 & $55.5-56$ & $\mathrm{Amb}$ & 642 & 586.4 & 623 & 4 & 3 & 912 & 70 & 886 & $<L O D$ \\
\hline MR5766c & 5766 & $56.5-57$ & $A m b$ & 1160 & 1223.0 & 1210 & 4 & 6 & 1240 & 359 & 1080 & $<L O D$ \\
\hline MR5766d & 5766 & $58-58.5$ & $\mathrm{Amb}$ & 686 & 641.2 & 621 & 2 & 2 & 266 & 640 & 1200 & 3390 \\
\hline MR5706a & 5706 & $42-43$ & Emp & 132 & 129.2 & 115 & 6 & 2 & 884 & 149 & 191 & 53 \\
\hline MR5706b & 5706 & $55-56$ & Emp & 28.5 & 21.7 & 40 & 0 & 0 & 50 & 7 & 520 & 8 \\
\hline MR5612a & 5612 & $41-42$ & Pri & $<\mathrm{LOD}$ & 5.8 & 2 & 6 & 3 & 4250 & 81 & 21 & $<L O D$ \\
\hline MR5612b & 5612 & $43-44$ & Pri & $<\mathrm{LOD}$ & ND & 3 & 3 & 1 & 744 & 223 & 19 & 1 \\
\hline MR5612c & 5612 & $45-46$ & Pri & 80.5 & $<L O D$ & 65 & 6 & 1 & 557 & 653 & 22 & 2 \\
\hline MR5613a & 5613 & $40-41$ & Pri & 5385.0 & 5614.0 & 5820 & 65 & 7 & 7000 & 83 & 2550 & 5120 \\
\hline MR5613b & 5613 & $41-43$ & Pri & 6296.0 & $<L O D$ & 4590 & 128 & 4 & 4650 & 289 & 1300 & 5780 \\
\hline MR5636 & 5636 & $55-56$ & Pri & $<\mathrm{LOD}$ & ND & 278 & 13 & 3 & 603 & 291 & 67 & 300 \\
\hline MR5728a & 5728 & $28.5-29$ & Sho & 903.0 & 5560 & 5590 & 6 & 1 & 974 & 0 & 1040 & 115 \\
\hline MR5728b & 5728 & $34-34.5$ & Sho & $<L O D$ & 125.1 & 113 & 3 & 0 & 166 & 1 & 99 & 109 \\
\hline
\end{tabular}


Supplementary Information

\begin{tabular}{|c|c|c|c|c|c|c|c|c|c|c|c|c|c|c|c|}
\hline sample number & core & $\begin{array}{l}\text { depth } \\
\text { m }\end{array}$ & deposit & $\begin{array}{c}\mathrm{Ga} \\
\mathrm{mg} \mathrm{kg}^{-1}\end{array}$ & $\begin{array}{c}\mathrm{Li} \\
\mathrm{mg} \mathrm{kg}{ }^{-1}\end{array}$ & $\begin{array}{c}\mathrm{Ni} \\
\mathrm{mg} \mathrm{kg}^{-1}\end{array}$ & $\begin{array}{c}\mathrm{Pb} \\
\mathrm{mg} \mathrm{kg}^{-1}\end{array}$ & $\begin{array}{c}\mathrm{Rb} \\
\mathrm{mg} \mathrm{kg}{ }^{-1}\end{array}$ & $\begin{array}{c}\mathrm{Sc} \\
\mathrm{mg} \mathrm{kg}^{-1}\end{array}$ & $\begin{array}{c}\mathrm{Ti} \\
\mathrm{mg} \mathrm{kg}^{-1}\end{array}$ & $\begin{array}{c}\text { Th } \\
\mathrm{mg} \mathrm{kg}^{-1}\end{array}$ & $\begin{array}{c}\mathrm{V} \\
\mathrm{mg} \mathrm{kg}^{-1}\end{array}$ & $\begin{array}{c}\text { W } \\
\mathrm{mg} \mathrm{kg}^{-1}\end{array}$ & $\begin{array}{c}\mathrm{Zn} \\
\mathrm{mg} \mathrm{kg}^{-1}\end{array}$ & $\begin{array}{c}\text { total REE }+Y \\
\mathrm{mg} \mathrm{kg}^{-1}\end{array}$ \\
\hline MR5076 & 5076 & $44.3-44.4$ & Amb & 3 & 81 & 1250 & 158 & 1.9 & 192 & 5270 & 44 & 145 & 1.1 & 1750 & 6270 \\
\hline MR5076 & 5076 & $44.7-44.8$ & Amb & $<\mathrm{LOD}$ & 13 & 8310 & 5290 & 2.4 & 1820 & 1850 & 10 & 312 & 0.6 & 3850 & 15400 \\
\hline MR5077 & 5077 & $42.2-42.5$ & Amb & 5 & 1 & 172 & 3650 & 0.8 & 427 & 10300 & 12 & 144 & 2.2 & 14 & 642 \\
\hline MR5078 & 5078 & $51.5-51.5$ & $A m b$ & 24 & 17 & 2050 & 2750 & 8.5 & 459 & 45500 & 49 & 493 & 9.2 & 770 & 4910 \\
\hline MR5766a & 5766 & $53-53.5$ & $A m b$ & 26 & 28 & 10800 & 379 & 2.4 & 915 & 24900 & 33 & 409 & 6.9 & 12800 & 5530 \\
\hline MR5766b & 5766 & $55.5-56$ & $A m b$ & 4 & 4 & 241 & 236 & 0.9 & 46 & 7460 & 13 & 48 & 3.1 & 1810 & 525 \\
\hline MR5766c & 5766 & $56.5-57$ & Amb & 4 & 3 & 940 & 600 & 0.8 & 88 & 6080 & 12 & 66 & 3.1 & 2560 & 698 \\
\hline MR5766d & 5766 & $58-58.5$ & Amb & 3 & 6 & 1250 & 458 & 1.6 & 51 & 5010 & 20 & 30 & 2.8 & 2280 & 234 \\
\hline MR5706a & 5706 & $42-43$ & Emp & 19 & 22 & 85 & 63 & 11.8 & 24 & 4970 & 24 & 98 & 2.6 & 10 & 291 \\
\hline MR5706b & 5706 & $55-56$ & Emp & 1 & 4 & 24 & 8 & 0.4 & 8 & 474 & 1 & 4 & 2.2 & 29 & 22 \\
\hline MR5612a & 5612 & $41-42$ & Pri & 2 & 9 & 232 & 7 & 1.2 & 29 & 6620 & 5 & 195 & 1.6 & 3810 & 601 \\
\hline MR5612b & 5612 & $43-44$ & Pri & 2 & 4 & 365 & 4 & 0.3 & 15 & 6940 & 10 & 39 & 4.0 & 2050 & 191 \\
\hline MR5612c & 5612 & $45-46$ & Pri & 18 & 16 & 1370 & 11 & 4.5 & 12 & 3100 & 7 & 35 & 5.0 & 7840 & 147 \\
\hline MR5613a & 5613 & $40-41$ & Pri & 5 & 3 & 362 & 2290 & 1.3 & 825 & 11100 & 201 & 148 & 3.9 & 1620 & 1710 \\
\hline MR5613b & 5613 & $41-43$ & Pri & 4 & 5 & 614 & 2090 & 1.1 & 330 & 7820 & 33 & 143 & 2.0 & $<\mathrm{LOD}$ & 948 \\
\hline MR5636 & 5636 & $55-56$ & Pri & 4 & 15 & 605 & 135 & 3.7 & 34 & 3550 & 11 & 30 & 1.5 & 1590 & 400 \\
\hline MR5728a & 5728 & $28.5-29$ & Sho & 49 & 6 & 4 & 465 & 4.0 & 377 & 8800 & 244 & 153 & 4.0 & 13 & 514 \\
\hline MR5728b & 5728 & $34-34.5$ & Sho & 1 & 2 & 1 & 6 & 0.4 & 7 & 1190 & 39 & 12 & 2.4 & $<$ LOD & 15 \\
\hline
\end{tabular}

SI Table 5 Elemental data for cores (2/2) 
Supplementary Information

SI Table 6 Summary of metals within deposits shown as average data in parts per million ( $\left.\mathrm{mg} \mathrm{kg}^{-1}\right)$

\begin{tabular}{|c|c|c|c|c|c|c|c|}
\hline Element & Mean & Min & Max & $\begin{array}{c}\text { Ambassador } \\
n=8\end{array}$ & $\begin{array}{l}\text { Emperor } \\
\qquad n=2\end{array}$ & $\begin{array}{c}\text { Princess } \\
n=6\end{array}$ & $\begin{array}{c}\text { Shogun } \\
n=2\end{array}$ \\
\hline As & 45.2 & 0.3 & 295.7 & 72.3 & 3 & 36.7 & 4.6 \\
\hline $\mathrm{Be}$ & 12.2 & 0.1 & 128.3 & 24.6 & 0.8 & 3.3 & 0.3 \\
\hline $\mathrm{Ca}$ & 2553 & 33.6 & 12950 & 3260 & 466.9 & 2966 & 569.9 \\
\hline Co & 614.8 & 0.5 & 4300 & 1161 & 78.2 & 270.1 & 0.6 \\
\hline $\mathrm{Cr}$ & 621 & 19.4 & 2552 & 668.8 & 355.7 & 662.7 & 570.1 \\
\hline $\mathrm{Cu}$ & 1696 & 0.9 & 7286 & 2325 & 30.1 & 2241 & 111.8 \\
\hline $\mathrm{Ga}$ & 9.6 & 0 & 48.8 & 8.3 & 10.1 & 6 & 24.8 \\
\hline $\mathrm{Li}$ & 13.4 & 0.9 & 80.5 & 19.2 & 13.1 & 8.8 & 4.1 \\
\hline $\mathrm{Ni}$ & 1594 & 0.7 & 10800 & 3128 & 54.5 & 591.1 & 2.5 \\
\hline $\mathrm{Pb}$ & 1033 & 3.7 & 5292 & 1690 & 35.5 & 754.7 & 235.9 \\
\hline $\mathrm{Rb}$ & 2.7 & 0.3 & 11.8 & 2.4 & 6.1 & 2 & 2.2 \\
\hline Sc & 314.4 & 6.8 & 1822 & 500 & 15.7 & 207.3 & 191.9 \\
\hline Th & 42.6 & 1.1 & 244.1 & 24 & 12.4 & 44.4 & 141.6 \\
\hline $\mathrm{Ti}$ & 8934 & 474.3 & 45450 & 13290 & 2720 & 6516 & 4997 \\
\hline U & 2798 & 1.9 & 14930 & 4219 & 77.9 & 1792 & 2853 \\
\hline V & 139 & 4.1 & 492.7 & 205.7 & 51.1 & 98.1 & 82.7 \\
\hline w & 3.2 & 0.6 & 9.2 & 3.6 & 2.4 & 3 & 3.2 \\
\hline $\mathrm{Zn}$ & 2673 & 10.1 & 12770 & 3225 & 19.6 & 3382 & 12.8 \\
\hline$R E E+Y$ & 2168 & 14.6 & 15390 & 4274 & 156.8 & 665.3 & 264.5 \\
\hline
\end{tabular}


Supplementary Information

SI Table 7 Correlations between $\mathrm{U}$ and metals; TOC and metals

\begin{tabular}{|c|c|c|c|c|}
\hline Correlation Test & $\mathrm{R}$ & $\mathrm{R}^{2}$ & p-value & significance \\
\hline U vs TOC & 0.377 & 0.142 & 0.1225 & $*$ \\
\hline U vs As & 0.861 & 0.741 & 0.0000 & $* * *$ \\
\hline U vs REE+Y & 0.805 & 0.649 & 0.0001 & $* * *$ \\
\hline U vs Ba & 0.14 & 0.02 & 0.5786 & ns \\
\hline U vs Ca & 0.345 & 0.119 & 0.1606 & $*$ \\
\hline U vs Cd & 0.816 & 0.666 & 0.0000 & $* * *$ \\
\hline U vs Mo & 0.195 & 0.038 & 0.4377 & $*$ \\
\hline U vs Ni & 0.602 & 0.363 & 0.0082 & $* *$ \\
\hline U vs $\mathrm{Pb}$ & 0.875 & 0.765 & 0.0000 & $* * *$ \\
\hline U vs Sn & 0.234 & 0.055 & 0.3491 & $*$ \\
\hline U vs Sr & 0.278 & 0.077 & 0.2641 & $*$ \\
\hline U vs Th & 0.282 & 0.08 & 0.2567 & $*$ \\
\hline U vs V & 0.577 & 0.333 & 0.0121 & $* *$ \\
\hline U vs Zr & 0.113 & 0.013 & 0.6548 & ns \\
\hline TOC vs As & 0.344 & 0.118 & 0.1626 & $*$ \\
\hline TOC vs REE+Y & 0.258 & 0.067 & 0.3006 & $*$ \\
\hline TOC vs Ba & 0.302 & 0.091 & 0.2233 & $*$ \\
\hline TOC vs Ca & 0.591 & 0.35 & 0.0097 & $* *$ \\
\hline TOC vs Cd & 0.145 & 0.021 & 0.5663 & ns \\
\hline TOC vs Mo & -0.069 & 0.005 & 0.7841 & ns \\
\hline TOC vs $\mathrm{Ni}$ & -0.01 & 0 & 0.9695 & ns \\
\hline TOC vs Pb & 0.457 & 0.208 & 0.0568 & $*$ \\
\hline TOC vs Sn & 0.349 & 0.122 & 0.1552 & $*$ \\
\hline TOC vs Sr & 0.54 & 0.291 & 0.0208 & $* *$ \\
\hline TOC vs Th & 0.184 & 0.034 & 0.4643 & $*$ \\
\hline TOC vs V & 0.481 & 0.231 & 0.0433 & $* *$ \\
\hline TOC vs Zr & 0.021 & 0 & 0.9349 & ns \\
\hline
\end{tabular}


Supplementary Information

SI Table 8 Results from the linear combination fitting. Two end-members were represented by synthetic uraninite (U(IV)) and mineral uranopilite (U(VI))

\begin{tabular}{|c|c|c|c|c|c|c|c|c|c|c|}
\hline \multirow[b]{2}{*}{ Data } & \multirow[b]{2}{*}{ Core } & \multirow[b]{2}{*}{ Rfactor } & \multirow[b]{2}{*}{ Chinu } & \multirow[b]{2}{*}{ chisqr } & \multirow[b]{2}{*}{ nvarys } & \multirow[b]{2}{*}{ scaleby } & \multicolumn{2}{|c|}{ uraninite } & \multicolumn{2}{|c|}{ Uranopilite } \\
\hline & & & & & & & weight & error & weight & error \\
\hline MR5766c & NNA 5766 & 0.0004 & $9.89 \mathrm{E}-05$ & 0.017 & 1 & 1 & 0.14 & 0.0043 & 0.86 & 0.0043 \\
\hline MR5766d & NNA 5766 & 0.011 & 0.0027 & 0.452 & 1 & 1 & 0.35 & 0.0226 & 0.65 & 0.0226 \\
\hline MR5713b & NNA 5613 & 0.008 & 0.0019 & 0.316 & 1 & 1 & 0.36 & 0.0188 & 0.64 & 0.0188 \\
\hline MR5713a & NNA 5613 & 0.0005 & 0.00013 & 0.022 & 1 & 1 & 0.12 & 0.0049 & 0.88 & 0.0049 \\
\hline MR5076a & NND 5076 & 0.006 & 0.0012 & 0.204 & 1 & 1 & 0.33 & 0.0151 & 0.67 & 0.0151 \\
\hline MR5077 & NND 5077 & 0.007 & 0.0016 & 0.266 & 1 & 1 & 0.24 & 0.0173 & 0.76 & 0.0173 \\
\hline MR5076b & NND 5076 & 0.002 & 0.0004 & 0.072 & 1 & 1 & 0.19 & 0.0090 & 0.81 & 0.0090 \\
\hline MR5766b & NNA 5766 & 0.003 & 0.0008 & 0.129 & 1 & 1 & 0.11 & 0.0120 & 0.89 & 0.0120 \\
\hline reduced_CD1577 & CD 1577 & 0.015 & 0.0025 & 0.419 & 1 & 1 & 0.65 & 0.0217 & 0.35 & 0.0217 \\
\hline oxidised_CD1577 & CD 1577 & 0.003 & 0.0005 & 0.091 & 1 & 1 & 0.16 & 0.0101 & 0.84 & 0.0101 \\
\hline U(IV) Synthetic uraninite & (Tsarev et al., 2016) & & & & & & 1 & & & \\
\hline U(VI) Natural uranopilite & M 40774 & & & & & & & & 1 & \\
\hline
\end{tabular}

46 


\section{Supplementary Information}

SI Table 9 Alternative EXAFS model using more MS paths

\begin{tabular}{|c|c|c|c|c|c|c|c|c|c|c|c|}
\hline Sample & Ligand & $\mathrm{N}$ & $\mathbf{R}(\mathbf{A})$ & ss $\left(\AA^{2}\right)$ & $\Delta \mathrm{E}_{0}$ & $\operatorname{Red} X^{2}$ & $r$-factor & $\begin{array}{c}\text { k-range } \\
(\AA)\end{array}$ & R-range (Å) & k-weighting & $\mathrm{SO}^{2}$ \\
\hline \multirow[t]{9}{*}{ MR5766c } & Oax2 & 1 & $1.75(4)$ & 0.003 (fix) & $7(1)$ & 111 & 0.025 & $2-12$ & $1.3-4$ & $1,2,3$ & 0.85 \\
\hline & Oax1 & 1 & $1.77(3)$ & 0.003 (fix) & & & & & & & \\
\hline & 015 & 2 & $2.20(1)$ & 0.003 (fix) & & & & & & & \\
\hline & 014 & 2 & $2.34(2)$ & 0.003 (fix) & & & & & & & \\
\hline & $\mathrm{OH} 2 \mathrm{O}$ & 2 & $2.39(2)$ & 0.003 (fix) & & & & & & & \\
\hline & c & 2 & $2.92(3)$ & 0.003 (fix) & & & & & & & \\
\hline & U-Oax2-U-Oax2 (MS) & & $3.51(6)$ & 0.006 (fix) & & & & & & & \\
\hline & U-Oax2-Oax1 (MS) & & $3.58(5)$ & 0.006 (fix) & & & & & & & \\
\hline & U-Oax2-U-Oax1 (MS) & & $3.58(5)$ & 0.006 (fix) & & & & & & & \\
\hline \multirow[t]{9}{*}{ MR5713a } & Oax2 & 1 & $1.77(10)$ & 0.003 (fix) & $9(3)$ & 111 & 0.025 & $3-11.5$ & $1.3-4$ & $1,2,3$ & 0.85 \\
\hline & Oax1 & 1 & $1.77(8)$ & $0.003(\mathrm{fix})$ & & & & & & & \\
\hline & 015 & 2 & $2.23(5)$ & 0.003 (fix) & & & & & & & \\
\hline & 014 & 2 & $2.38(4)$ & 0.003 (fix) & & & & & & & \\
\hline & $\mathrm{OH} 2 \mathrm{O}$ & 2 & $2.43(6)$ & 0.003 (fix) & & & & & & & \\
\hline & c & 2 & $2.89(7)$ & 0.003 (fix) & & & & & & & \\
\hline & U-Oax2-U-Oax2 (MS) & & $3.54(11)$ & 0.006 (fix) & & & & & & & \\
\hline & U-Oax2-Oax1 (MS) & & $3.58(13)$ & 0.006 (fix) & & & & & & & \\
\hline & U-Oax2-U-Oax1 (MS) & & $3.58(13)$ & 0.006 (fix) & & & & & & & \\
\hline \multirow[t]{9}{*}{ oxidised_CD1577* } & Oax2 & 1 & $1.75(4)$ & 0.003 (fix) & $7(1)$ & 111 & 0.025 & $2.5-12$ & $1-4$ & $1,2,3$ & 0.85 \\
\hline & Oax1 & 1 & $1.77(3)$ & 0.003 (fix) & & & & & & & \\
\hline & 015 & $2.8(4)$ & $2.20(1)$ & 0.003 (fix) & & & & & & & \\
\hline & 014 & 2 & $2.34(2)$ & 0.003 (fix) & & & & & & & \\
\hline & $\mathrm{OH} 2 \mathrm{O}$ & 2 & $2.39(2)$ & 0.003 (fix) & & & & & & & \\
\hline & c & 2 & $2.88(4)$ & $0.003(\mathrm{fix})$ & & & & & & & \\
\hline & U-Oax2-U-Oax2 (MS) & & $3.50(6)$ & 0.006 (fix) & & & & & & & \\
\hline & U-Oax2-Oax1 (MS) & & $3.58(5)$ & 0.006 (fix) & & & & & & & \\
\hline & U-Oax2-U-Oax1 (MS) & & $3.58(5)$ & 0.006 (fix) & & & & & & & \\
\hline
\end{tabular}

$50 *$ these distances were constrained to be the same as those of MR5766c these 3 data sets were fitted together. 
Supplementary Information

51

SI Figure 1 XRD spectra

52

A) Uranyl nitrate Patterns were collected with a Bruker D8 Advance Eco diffractometer equipped with a LYNXEYE XE linear position sensitive detector and using a Cu X-ray tube operated at $40 \mathrm{kV}$ and $25 \mathrm{~mA}$.

54 Data were collected from $3-80^{\circ} 2 \theta$ with a step size of $0.02^{\circ} 2 \theta$ and a counting rate of $1 \mathrm{~s} / \mathrm{step}$. Minerals were identified with reference to standard patterns from the ICDD Powder Diffraction File 2 (PDF-2) database using the DIFFRAC.EVA v.4 software package (available from Bruker AXS).

57

\section{UO2NO3-pure-EtOH-smear-qtz-1s (Coupled TwoTheta/Theta)}



58

60

61

62

63

64 


\section{Supplementary Information}

65

66

67

68

69

B) Background of CD1577. Data were measured using a Bruker GADDS microdiffractometer, using Cu Ka radiation from an X-ray tube operating at $40 \mathrm{~mA}, 40 \mathrm{kV}$. The incident beam was passed through crossed reflecting (Gobel) mirrors, resulting in a monochromatic, parallel, high-brilliance source which was then collimated through a $200 \mu \mathrm{m}$ pinhole system. The spectrum was consistent with quartz alpha mixed with an unidentified minor phase.

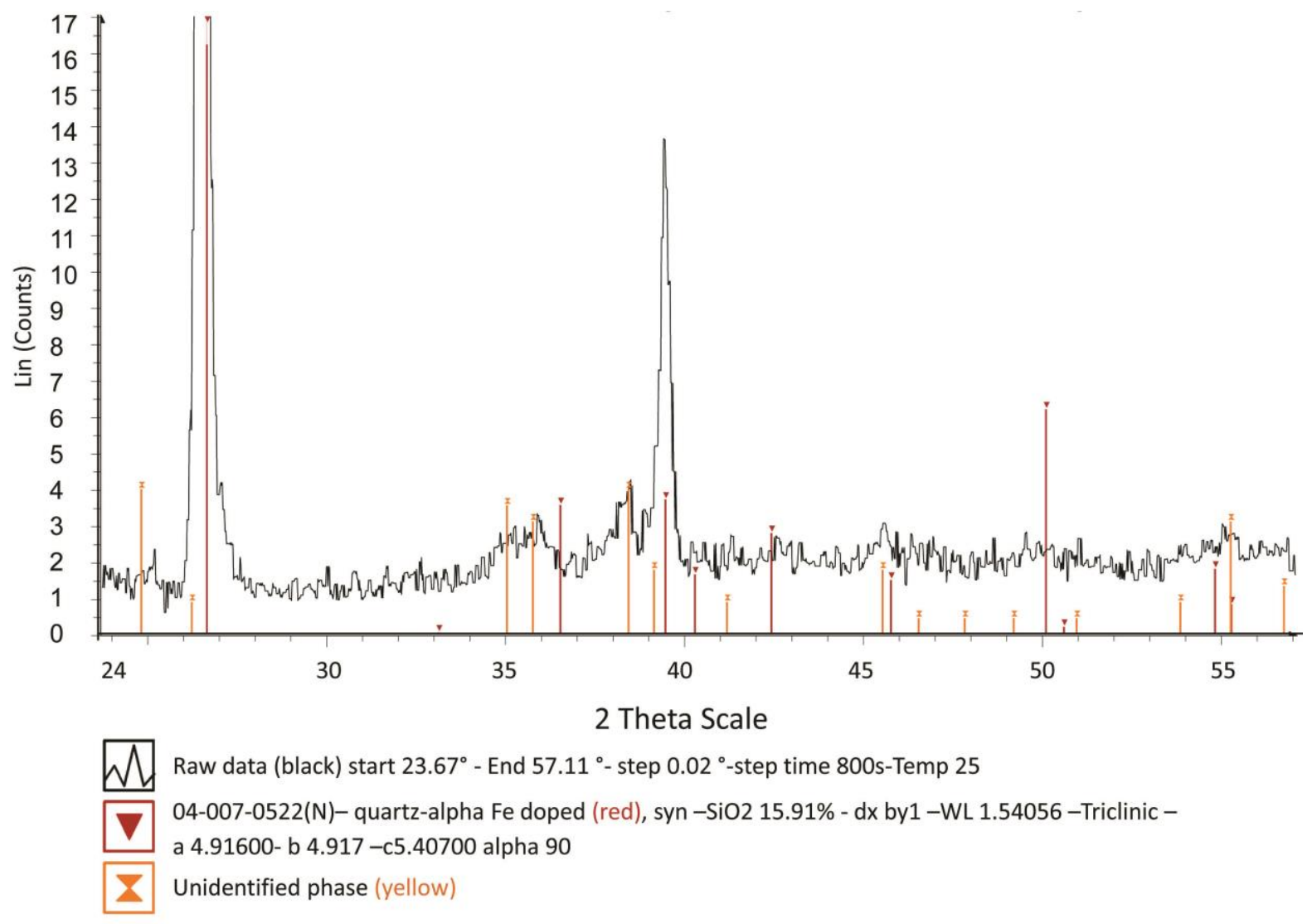

71

72

73

74

75 
Supplementary Information

C) Coffinite- Micro-XRD pattern of mineralised area of uranium, spot analysis was taken at the edge of a pyrite grain. Red lines show markers corresponding to U(IV) coffinite pattern (USiO $)$ (RRUFF). Beam = $300 \mu \mathrm{m}$ Cu Ka collimator.

79



80

81 
82 SI Figure 2 U L3 edge XAS x-ray absorption of the near edge structure for spectra of bulk cores and of some 83 mineral standards
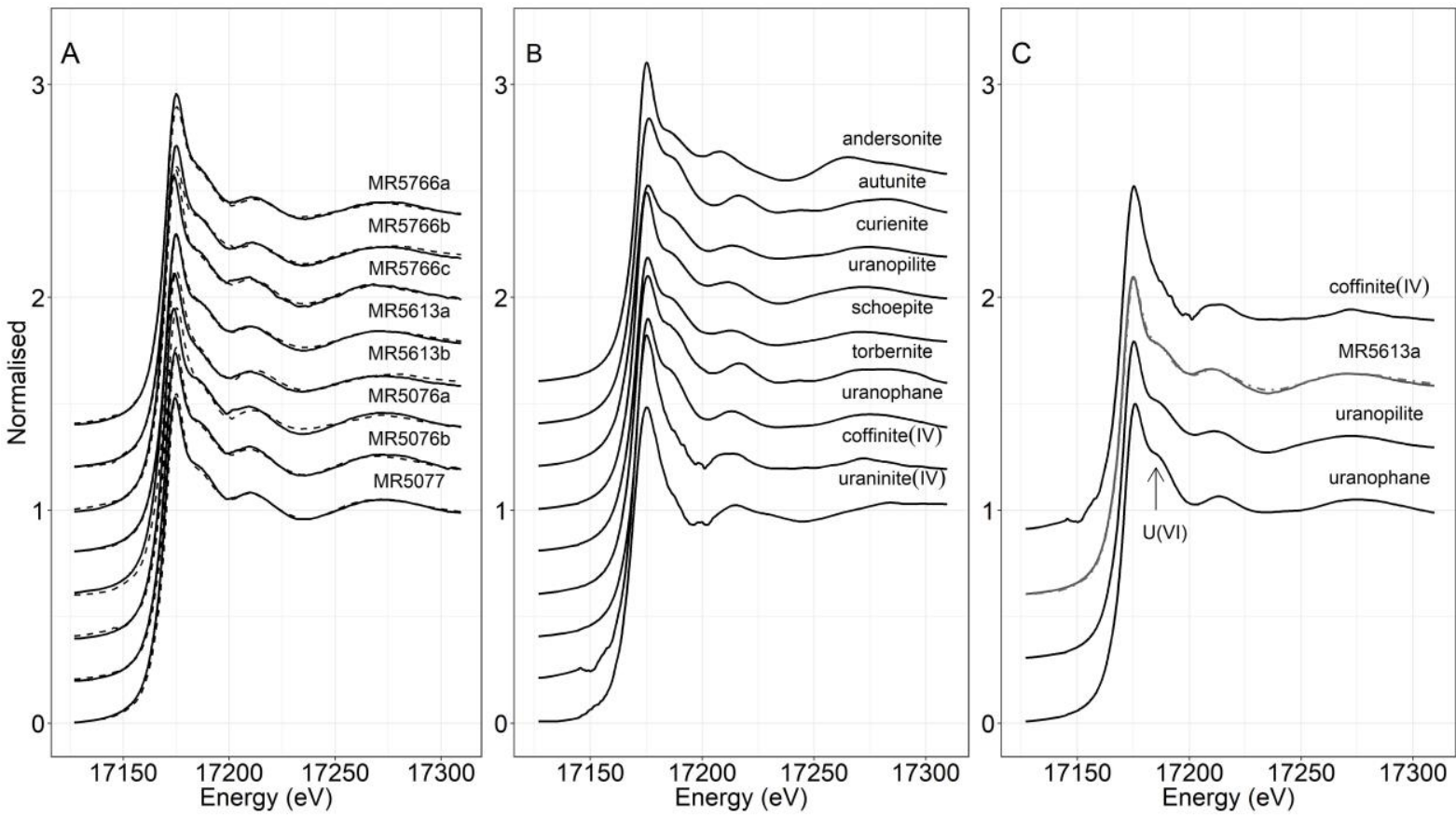

85

SI Figure $3 \cup$ L3 edge XAS - Extended $x$-ray absorbance of the fine structure shown in $K^{2}$ space. Top four spectra are fitted EXAFS of the bulk cores where solid line is the sample. The $U(I V)$ and $U(V I)$ lignite samples were from a thin section of MR lignite (CD 1577). The bottom seven spectra are mineral standards donated by Museum Victoria.

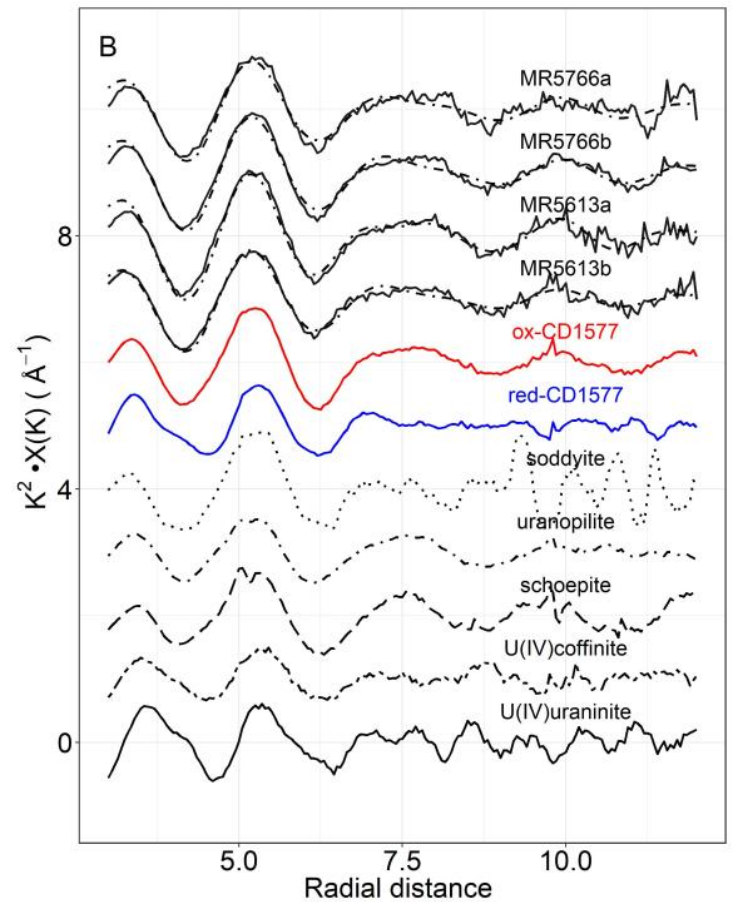


Supplementary Information

SI Figure 4 EDS-SEM map and spectra from CD1577

93
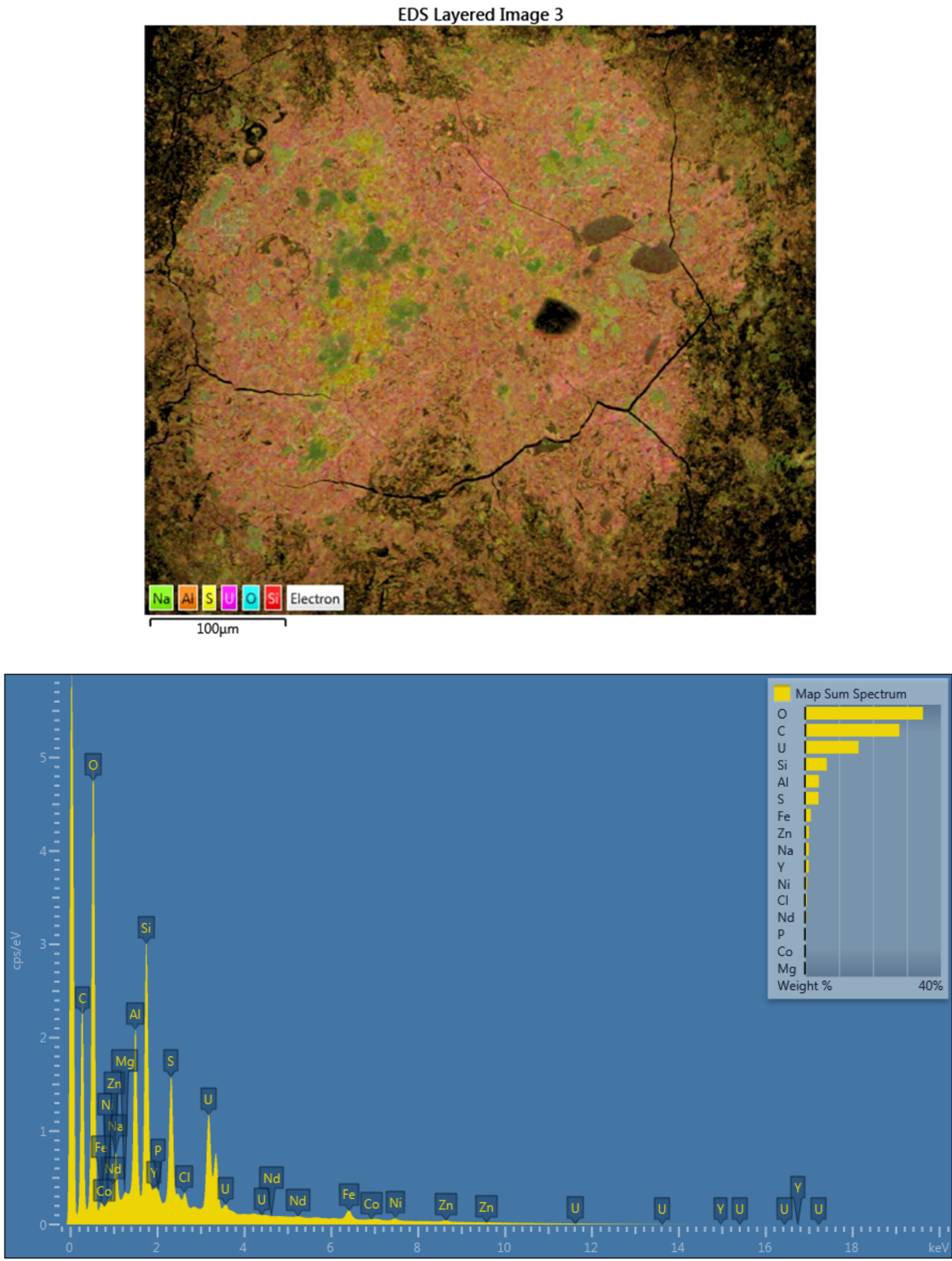